\title{
Epimedium koreanum Nakai inhibits PMA-induced cancer cell migration and invasion by modulating NF-кB/MMP-9 signaling in monomorphic malignant human glioma cells
}

\author{
WONIL LEE $^{1 *}$, JIN HAN NAM $^{1 *}$, HYUN-JI CHO $^{1 *}$, JU-YOUNG LEE $^{1 *}$, WON-KYUNG CHO ${ }^{3}$, \\ YEONGYEON KIM ${ }^{1}$, YOUNG-MAN WE ${ }^{2}$, JIN YEUL MA ${ }^{3}$ and HYANG-SOOK HOE ${ }^{1}$ \\ ${ }^{1}$ Department of Neural Development and Disease, Korea Brain Research Institute (KBRI), Dong-gu, Daegu 41062; \\ ${ }^{2}$ Oriental Medical Clinic Center, Hyoo Medical Clinic, Gangnam-gu, Seoul 06134; ${ }^{3}$ Korean Medicine (KM)- \\ Application Center, Korea Institute of Oriental Medicine (KIOM), Dong-gu, Daegu 41068, Republic of Korea
}

Received May 18, 2017; Accepted September 26, 2017

DOI: 10.3892/or.2017.6043

\begin{abstract}
Previously, we showed that the herbal extract EYK (Epimedium koreanum Nakai) can regulate the immune response. Other studies showed that EYK has beneficial effects in human lung cancer, angiogenesis and Alzheimer's disease (AD). However, it remains unknown whether EYK can affect cancer cell migration and invasion in human brain cancer cell lines. In the present study, we found that pre- or post-treatment with EYK inhibited phorbol 12-myristate 13-acetate (PMA)-induced cancer cell migration and invasion in A172 cells, but not in U373MG or T98G cells. Additionally, pre- or post-treatment with PMA followed by EYK decreased MMP-9 activity in A172 cells. Moreover, treatment with a $\mathrm{NF}-\kappa \mathrm{B}$ inhibitor significantly decreased cell migration in A172 cells pre- or post-treated with EYK and PMA, suggesting that EYK requires $N F-\kappa B$ to alter cancer cell migration. Either pre- or post-treatment with EYK significantly decreased $\mathrm{NF}-\kappa \mathrm{B}$ nuclear translocation in comparison with PMA treatment. Taken together, our results suggest that EYK suppresses PMA-induced cancer cell migration in monomorphic malignant human glioma cells by downregulating the $\mathrm{NF}-\kappa \mathrm{B}$ pathway and decreasing MMP-9 activity.
\end{abstract}

Correspondence to: Dr Hyang-Sook Hoe, Department of Neural Development and Disease, Korea Brain Research Institute (KBRI), 61 Cheomdan-ro, Dong-gu, Daegu 41062, Republic of Korea E-mail: sookhoe72@kbri.re.kr

Dr Jin Yeul Ma, Korean Medicine (KM)-Application Center, Korea Institute of Oriental Medicine (KIOM), 70 Cheomdan-ro, Dong-gu, Daegu 41068, Republic of Korea

E-mail: jyma@kiom.re.kr

*Contributed equally

Key words: epimedium koreanum Nakai, cell migration, malignant human glioma cell, phorbol 12-myristate 13 -acetate, $\mathrm{NF- \kappa B}$

\section{Introduction}

EYK, a herbal plant-based extract derived from Epimedium koreanum Nakai, consists of multiple elements including anhydroicaritin-3-O- $\alpha$-L-rhamnopyranoside, icariin, icariside II quercetin, epimedin A, epimedin B, ikarisoside, b-sitosterol, daucosterol, campesterol, epimediphine and chlorogenic acid (1). Icariin, acting through the phosphoinositide 3-kinase and protein kinase B (PI3/AKT) and nuclear factor-kappa B (NF- $\mathrm{B}$ ) pathways, inhibits lipopolysaccharide (LPS)-induced lung inflammation (2). EYK decreases the abundance of $\beta$-amyloid plaque (A $\beta$ ) in APP transgenic mice (3) and inhibits adipocyte differentiation by downregulating adipogenic transcription factors in 3T3-L1, a murine preadipocyte cell line (4). Another constituent, icariside II, promotes terminal deoxynucleotidyl transferase dUTP nick end labeling (TUNEL)-positive apoptosis in PC-3 prostate carcinoma cells (5) and exerts antitumor activity in human adenocarcinoma alveolar basal epithelial A549 cells via the mitochondria apoptotic pathway, including bcl2-related $\mathrm{X}$ protein/B-cell lymphoma $2(\mathrm{BAX} / \mathrm{Bcl}-2)$ as well as the caspase signaling pathway (6). EYK also has antiviral activity against porcine epidemic diarrhea virus (PEDV), which induces diarrhea in adult pigs and suppresses viral replication in both PEDV-infected cell lines and piglets (7). Thus, EYK extracts confer beneficial effects in various diseases, including human lung cancer (6), prostate carcinoma (5), myeloid acute leukemia (8), angiogenesis (9), Alzheimer's disease (3) and inflammatory conditions (2). However, it is still not clear whether EYK can affect cancer cell metastasis in human glioblastoma.

Human glioblastoma multiforme (GBM) is a type of brain cancer that arises from astrocytes. Brain cancer is accompanied by symptoms such as seizure, abnormal behavior and memory deficits. Currently, brain tumors are treated by surgery, radiation therapy and chemotherapy with temozolomide (TMZ). However, this regimen can also damage healthy tissues (10) and some cases of GBM are resistant to TMZ therapy $(11,12)$. TMZ is an anti-neoplastic agent that delivers methyl groups to purine bases (guanine at N7 and O6 and adenine at N3) in 
DNA of cancer cells, inducing DNA damage and ultimately leading to apoptosis and cytotoxicity. Clinical studies showed that TMZ induces side-effects such as myelosuppression, nausea and vomiting (13). Thus, a new anti-brain cancer drug is necessary for the successful treatment and cure of GBM.

In the present study, we examined the effect of EYK on brain cancer cell migration and invasion. We found that preor post-treatment with EYK inhibited cancer cell migration and invasionin monomorphic malignant human glioma cells. We observed that EYK required matrix metalloprotease-9 (MMP-9) activity to inhibit phorbol 12-myristate 13-acetate (PMA)-induced cancer cell migration. In addition, pre- or post-treatment with EYK regulated $N F-\kappa B$ nuclear translocation in PMA-induced A172 cells. Moreover, treatment with $\mathrm{NF}-\kappa \mathrm{B}$ inhibitor followed by EYK significantly suppressed cell migration in PMA-induced A172 cells in comparison with treatment with PMA and NF- $\kappa$ B inhibitor or PMA and EYK. Taken together, our results suggest that EYK inhibits cell migration in monomorphic malignant human glioma cells by downregulating the NF- $\kappa \mathrm{B}$ nuclear translocation and thereby decreasing MMP-9 activity.

\section{Materials and methods}

Preparation of Epimedium koreanum Nakai. Epimedium koreanum Nakai (EYK) was as described in our previous studies (7). Briefly, the dried bark of the plant was obtained from a domestic Korean market (Kyung Dong Crude Drugs Market, Seoul, Korea) and boiled in distilled water for $2.5 \mathrm{~h}$ at $105^{\circ} \mathrm{C}$; the resultant suspension was filtered and lyophilized. The powder was stored at $4^{\circ} \mathrm{C}$ and the extract was dissolved in phosphate-buffered saline (PBS) and diluted with medium before each experiment.

Cell lines and culture conditions. A172, U373MG and T98G cells (human brain cancer cells; Korean Cell Line Bank, Seoul, Korea) were maintained in RPMI-1640 medium (HyClone Laboratories, Logan, UT, USA) supplemented with $10 \%$ fetal bovine serum (FBS; HyClone Laboratories) in a $5 \%$ $\mathrm{CO}_{2}$ incubator.

Antibodies and inhibitors. We used the following primary antibodies: mouse $\beta$-actin (Santa Cruz Biotechnology, Dallas, TX, USA), mouse anti-p-IкB $\alpha$ (B-9, Ser32; Santa Cruz Biotechnology), rabbit anti-I $\mathrm{B} \alpha$ (Santa Cruz Biotechnology), rabbit anti-NF-кB (P65; Santa Cruz Biotechnology), PCNA (Abcam, Cambridge, MA, USA), rabbit anti-ERK (Cell Signaling Technology, Danvers, MA, USA), rabbit antip-ERK (Thr202/Tyr204; Cell Signaling Technology) and rabbit anti-p-NF-кB (Ser536; Cell Signaling Technology). The following secondary antibodies and dilutions were used: horseradish peroxidase (HRP)-conjugated anti-mouse and rabbit IgG (Bethyl Laboratories, Montgomery, TX, USA). Phorbol 12-myristate 13-acetate (PMA), MMP-9 inhibitor (CAS1177749-58-4) and NF- $\kappa$ B inhibitor (BAY 11-7085) were purchased from Sigma-Aldrich (St. Louis, MO, USA).

Western blotting. Western blot analysis was performed as previously described (14). Briefly, A172, U373MG and T98G cells were harvested in ice-cold lysis buffer $(50 \mathrm{mM}$ Tris-Cl,
$150 \mathrm{mM} \mathrm{NaCl}, 1 \% \mathrm{NP}-40$ ) containing protease and phosphatase inhibitor (Roche Diagnostics, Indianapolis, IN, USA). Proteins from cell extracts were separated under denatured and reduced conditions using Tris-glycine polyacrylamide gel electrophoresis. Separated proteins were transferred onto polyvinylidene difluoride membrane (PVDF; EMD Millipore, Temecula, CA, USA) at $110 \mathrm{~V}$ for $1 \mathrm{~h}$ and blocked with $5 \%$ skim milk or $5 \%$ bovine serum albumin (BSA) in $0.1 \%$ TBS-T (Tris-buffered saline with $0.1 \%$ Tween-20) for $1 \mathrm{~h}$ at room temperature. The blots were incubated overnight at $4^{\circ} \mathrm{C}$ with specific primary antibodies: mouse $\beta$-actin (1:5,000; Santa Cruz Biotechnology), mouse anti-p-IкB $\alpha$ (Ser32, 1:500; Santa Cruz Biotechnology), rabbit anti-I $\mathrm{B} \alpha$ (1:1,000; Santa Cruz Biotechnology), rabbit anti-NF- $\mathrm{B}$ (P65, 1:1,000; Santa Cruz Biotechnology), rabbit anti-ERK (Cell Signaling Technology), rabbit anti-p-ERK (Thr202/ Tyr204; Cell Signaling Technology), and PCNA (1:1,000; Abcam). HRP-conjugated secondary antibody was visualized by enhanced chemiluminescence detection reagents (ECL; ATTO Corp., Tokyo, Japan) and image were captured using chemiluminescence imaging system (Vilber Lourmat Deutschland GmbH, Eberhardzell, Germany). Equal amount of protein (10 mg) were used for immunoblotting and all blot images were analyzed using either Fusion software or ImageJ.

MTT assays. To measure cell viability, A172, U373MG and T98G cells were seeded in 96-well plates and treated for $24 \mathrm{~h}$ with vehicle or EYK at various concentrations (1, 10, 100, 200, or $400 \mu \mathrm{g} / \mathrm{ml})$ in the absence of serum. After $24 \mathrm{~h}$, cells were treated with $0.5 \mathrm{mg} / \mathrm{ml} \mathrm{MTT}$ and incubated for $3 \mathrm{~h}$ at $37^{\circ} \mathrm{C}$ in a $5 \% \mathrm{CO}_{2}$ incubator. Plates were read by measuring absorbance at $580 \mathrm{~nm}$.

Cell migration (wound healing assay). A172, U373MG and T98G cells were $80 \%$ confluence, and then the monolayer of cells was scratched using a fine pipette tip and immediately imaged $(0 \mathrm{~h})$. The cells were pre-treated with vehicle or PMA $(75 \mathrm{nM})$ for $45 \mathrm{~min}$, and then treated with vehicle or EYK $(200 \mu \mathrm{g} / \mathrm{ml})$ for $24 \mathrm{~h}$. Images of the wound gap were acquired immediately $(0 \mathrm{~h})$ and $24 \mathrm{~h}$ after $(24 \mathrm{~h})$ scratching and gap width was measured using ImageJ.

Transwell invasion assay. Corning Matrigel ${ }^{\circledR}$ was loaded onto the membrane of a culture insert (Corning Transwell System; Corning Inc., Corning, NY, USA) and incubated at $37^{\circ} \mathrm{C}$ for $30 \mathrm{~min}$ in a $5 \% \mathrm{CO}_{2}$ incubator. A172 cells $\left(1 \times 10^{5} / \mathrm{ml}\right)$ were plated onto the Matrigel-coated insert in the upper chamber, which contained serum-free RPMI-1640, and then treated with vehicle, EYK (200 $\mu \mathrm{g} / \mathrm{ml})$ or PMA (75 nM). RPMI-1640 media containing $10 \%$ FBS was added to the lower chamber. After $24 \mathrm{~h}$, the cells were fixed in methanol (100\%) and stained with hematoxylin-eosin (Sigma-Aldrich). The membrane was cut and mounted on a glass microscope slide. Images were randomly acquired (two or three images from each sample) on aninverted microscope (Carl Zeiss, Oberkochen, Germany).

Gelatin zymography assay. To measure MMP activity, A172 cells were pre-treated with vehicle or PMA $(75 \mathrm{nM})$ for $45 \mathrm{~min}$, and then treated for $24 \mathrm{~h}$ with vehicle or EYK $(200 \mu \mathrm{g} / \mathrm{ml})$. After $24 \mathrm{~h}$, the conditioned medium was collected and analyzed on a 
$10 \%$ acrylamide gel containing $0.1 \%(\mathrm{w} / \mathrm{v})$ gelatin. Following electrophoresis, the gel was washed three times for $10 \mathrm{~min}$ each with $2.5 \%$ Triton X-100, and then incubated overnight in zymography incubation buffer $\left(2.5 \mathrm{mM} \mathrm{CaCl}_{2}, 200 \mathrm{mM} \mathrm{NaCl}\right.$, $50 \mathrm{mM}$ Tris- $\mathrm{HCl}, \mathrm{pH} 7.5)$. The next day, the gel was stained with $0.2 \%$ Coomassie brilliant blue solution R-250 for $1 \mathrm{~h}$, and then washed three times for $10 \mathrm{~min}$ each in destaining buffer (10\% MeOH, $10 \%$ acetic acid in distilled water). Gel images were acquired on a light box (Vilber Lourmat, Seoul, Korea) and analyzed using Image Gauge V4.0 (Fujifilm, Tokyo, Japan).

Cytosolic and nuclear fractionation. A172 cells were lysed on ice for $5 \mathrm{~min}$ in buffer A [10 mM HEPES (pH 8.0), $1.5 \mathrm{mM}$ $\mathrm{MgCl}_{2}, 10 \mathrm{mM} \mathrm{KCl}, 0.5 \mathrm{mM}$ DTT, $300 \mathrm{mM}$ sucrose, $0.1 \%$ NP-40 and $0.5 \mathrm{mM}$ PMSF]. After $5 \mathrm{~min}$, the cell lysates were centrifuged at $10,000 \mathrm{rpm}$ at $4^{\circ} \mathrm{C}$ for $1 \mathrm{~min}$, and the supernatant was collected as the cytosolic fraction. Then, the cell pellet was lysed on ice for $15 \mathrm{~min}$ in buffer B [20 mM HEPES (pH 8.0), 20\% glycerol, $100 \mathrm{mM} \mathrm{KCl}, 100 \mathrm{mM} \mathrm{NaCl}, 0.2 \mathrm{mM}$ EDTA, $0.5 \mathrm{mM}$ DTT and $0.5 \mathrm{mM}$ PMSF] and the cell lysates were centrifuged at $15,000 \mathrm{rpm}$ at $4^{\circ} \mathrm{C}$ for $20 \mathrm{~min}$. The supernatant was collected as the nuclear fraction.

$R T-P C R$. To examine the effects of EYK on $M M P-9$ and TIMP-1 mRNA levels, A172 cells were pre-treated with vehicle or PMA (75 $\mathrm{nM}$ ) for $45 \mathrm{~min}$, and then treated for $24 \mathrm{~h}$ with vehicle or EYK $(200 \mu \mathrm{g} / \mathrm{ml})$. After $24 \mathrm{~h}$, RNA was extracted using TRIzol (Ambion, Inc., Austin, TX, USA). RT-PCR was performed using the following primers: $M M P-9$ : 5'-CGG AGC ACG GAG ACG GGT AT and 3'-TGA AGG GGA AGA CGC ACA GC; TIMP-1: 5'-AGC GCC CAG AGA GAC ACC and 3'-CCA CTC CGG GCA GGA TT; GAPDH: 5'-GTT ACC AGG GCT GCC TTC TC and 3'-GTG ATG GCA TGG ACT GTG GT. Image analyses were performed using the Fusion or ImageJ software to measure average band intensities.

Immunocytochemistry. A172 and U373MG cells were fixed for 8 min using ice cold $100 \%$ methanol, washed with $1 \mathrm{X}$ PBS, and then incubated with the following primary anti-

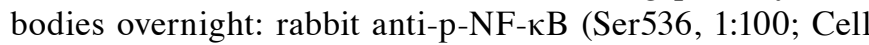
Signaling Technology), mouse anti- $\beta$-actin (1:200; Santa Cruz Biotechnology) in GDB buffer $(0.1 \%$ gelatin, $0.3 \%$ Triton X-100, $16 \mathrm{mM}$ sodium phosphate $\mathrm{pH} 7.4$ and $450 \mathrm{mM}$ $\mathrm{NaCl}$ ) overnight at $4^{\circ} \mathrm{C}$. The next day, cells were washed with $1 \mathrm{X}$ PBS three times and incubated with the following secondary antibodies in GDB solution for $1 \mathrm{~h}$ at room temperature: anti-rabbit-AlexaFluor 488 and anti-mouse-AlexaFluor 555 (1:200; Molecular Probes, Eugene, OR, USA) and cell covered using DAPI containing mount solution (Vector Laboratories, Burlingame, CA, USA). Images were taken on a single plane using a confocal microscope (Nikon) and analyzed using ImageJ software.

Statistical analyses. All data were analyzed by either twotailed t-test or ANOVA using the GraphPad Prism 4 software. Post hoc analyses were completed with the Tukey's multiple comparison test with $\mathrm{P}<0.05$ considered to represent significance $(\mathrm{P}<0.05, \mathrm{P}<0.01, \mathrm{P}<0.001)$.

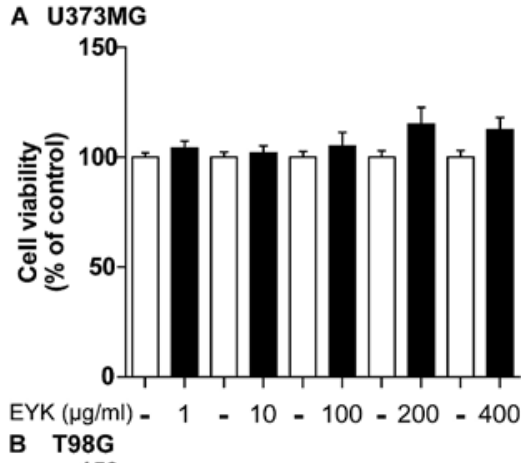

B T98G

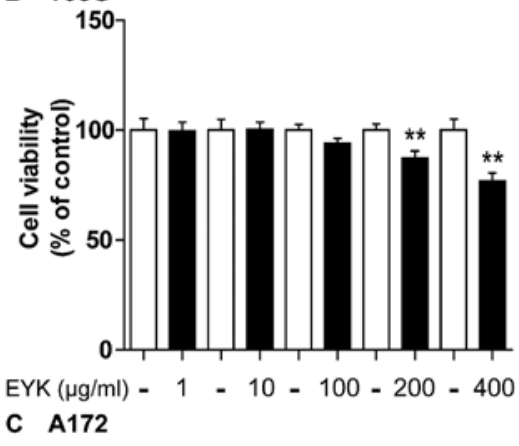

C $\mathbf{A 1 7 2}$

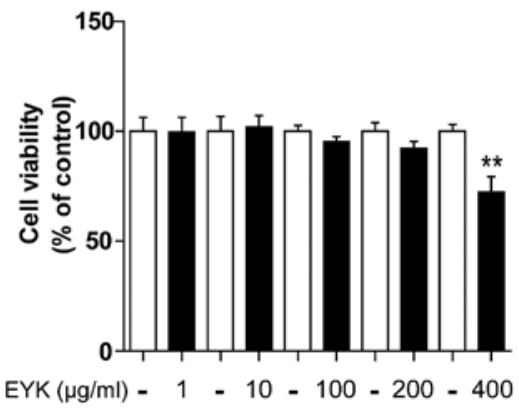

Figure 1. Effect of EYK on cell viability in malignant human glioma cells (A) U373MG, (B) T98G and (C) A172 cells were treated with vehicle or EYK $(1,10,100,200$ or $400 \mu \mathrm{g} / \mathrm{ml})$ for $24 \mathrm{~h}$, and then MTT assays were performed (U373MG: $n=16$ for each dose; T98G: $n=8$ for each dose; A172: $n=16$ for each dose; ${ }^{* *} \mathrm{P}<0.01$; two-tailed t-test).

\section{Results}

EYK inhibits PMA-induced cell migration in A172 cells. To test the effects of EYK on cell viability in malignant human tumor cells, we treated U373MG, T98G and A172 cells with vehicle or EYK $(1,10,100,200$ or $400 \mu \mathrm{g} / \mathrm{ml})$ for $24 \mathrm{~h}$ and then conducted MTT assays. In U373MG cells, EYK did not influence cell viability at any doses (Fig. 1A). In T98G cells, EYK slightly decreased cell viability at the highest doses, by 13 and $23 \%$ at 200 and $400 \mu \mathrm{g} / \mathrm{ml}$, respectively (Fig. $1 \mathrm{~B}, \mathrm{P}<0.01$; two-tailed t-test). In A172 cells, EYK caused no toxicity up to a concentration of $200 \mu \mathrm{g} / \mathrm{ml}$, but had some toxicity at $400 \mu \mathrm{g} / \mathrm{ml}$ (Fig. 1C, $\mathrm{P}<0.01$; two-tailed t-test). Based on these findings, we selected a working concentration of $200 \mu \mathrm{g} / \mathrm{ml}$ for the following experiments.

To determine whether EYK can regulate PMA-induced brain tumor cell migration, we initially optimized the dose and timing for treatment with PMA, a cancer inducer (15), in our culture system. For these experiments, U373MG, T98G and A172 cells were grown in a monolayer, scratched with a pipette tip, and treated with vehicle or PMA $(25,50$, 75,100 or $125 \mathrm{nM}$ ) for $24 \mathrm{~h}$. At $0 \mathrm{~h}$ (i.e., immediately after 

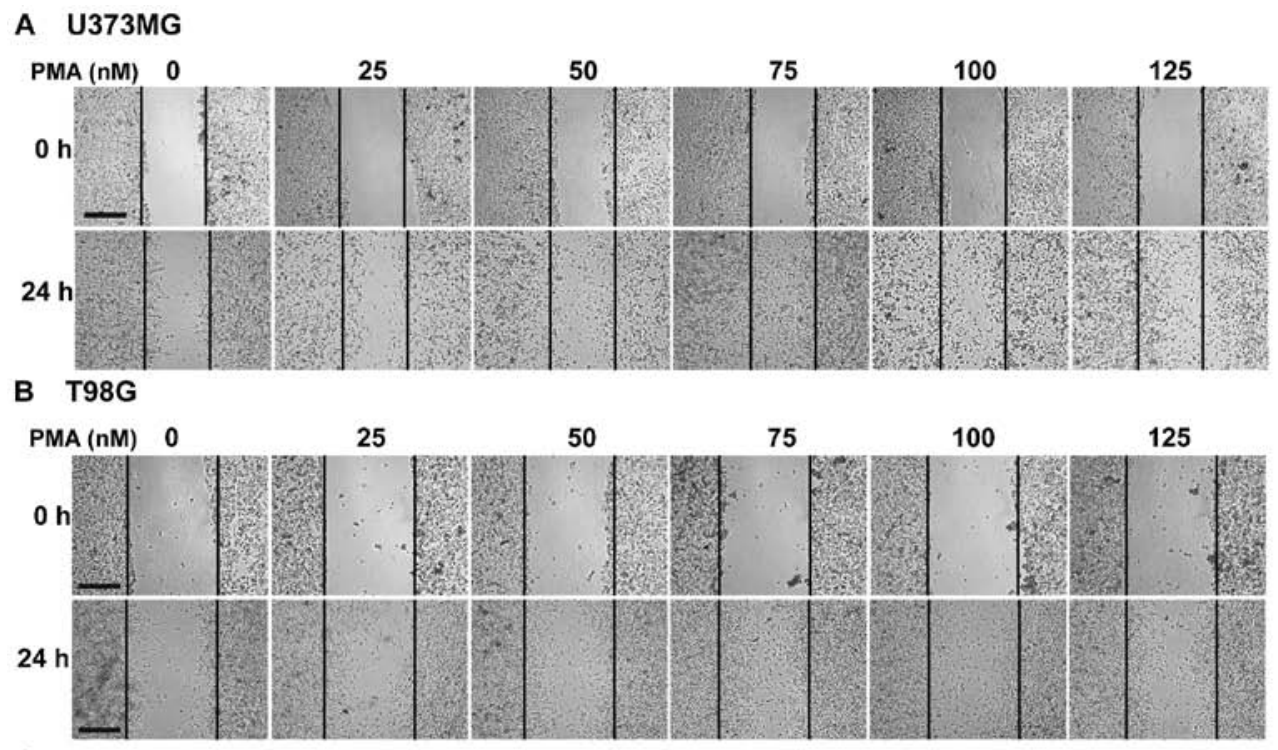

C $\mathbf{A 1 7 2}$
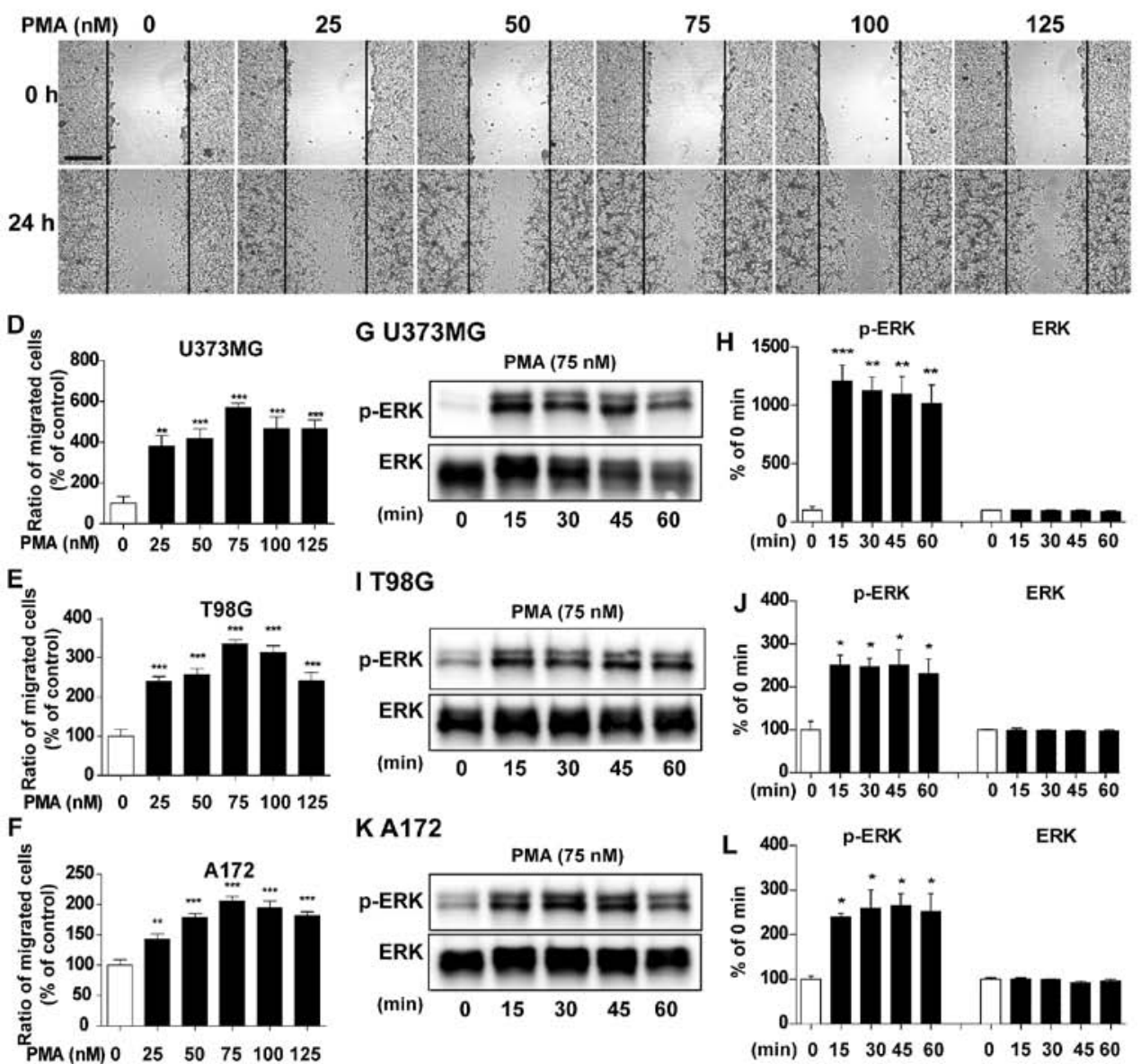

Figure 2. Dose- and time-dependent effects of PMA on cell migration and signaling. (A) U373MG, (B) T98G and (C) A172 cell monolayers were scratched with a pipette tip and then treated with vehicle or PMA $(25,50,75,100$ or $125 \mathrm{nM})$ for $24 \mathrm{~h}$. Images of the wound gap were acquired at $0 \mathrm{~h}$ (i.e., immediately after scratching) and after $24 \mathrm{~h}$. (D-F) Quantification of data from (A) (U373MG: PMA 0 nM, n=9; PMA 25 nM, n=7; PMA 50 nM, n=9; PMA 75 nM, n=12; PMA $100 \mathrm{nM}, \mathrm{n}=10$; PMA $125 \mathrm{nM}, \mathrm{n}=12 ;{ }^{* *} \mathrm{P}<0.01 ;{ }^{* * *} \mathrm{P}<0.001$; ANOVA with post hoc Tukey's test), (B) (T98G: PMA $0 \mathrm{nM}, \mathrm{n}=11 ;$ PMA $25 \mathrm{nM}, \mathrm{n}=11$; PMA $50 \mathrm{nM}, \mathrm{n}=9$; PMA $75 \mathrm{nM}, \mathrm{n}=14$; PMA $100 \mathrm{nM}, \mathrm{n}=13$; PMA $125 \mathrm{nM}, \mathrm{n}=11$; ${ }^{* * *} \mathrm{P}<0.001$, ANOVA with post hoc Tukey's test), and (C) (A172: PMA $0 \mathrm{nM}, \mathrm{n}=11$; PMA $25 \mathrm{nM}, \mathrm{n}=10$; PMA $50 \mathrm{nM}, \mathrm{n}=9$; PMA $75 \mathrm{nM}, \mathrm{n}=9$; PMA $100 \mathrm{nM}, \mathrm{n}=9$; PMA $125 \mathrm{nM}, \mathrm{n}=10$; ${ }^{* *} \mathrm{P}<0.01,{ }^{* * * *} \mathrm{P}<0.001$, ANOVA with post hoc Tukey's test). (G) U373MG, (I) T98G and (K) A172 cells were treated with PMA (75 nM) or vehicle for 15, 30, 45 or 60 min, and western blotting was performed with anti-p-ERK and ERK antibodies. (H, J and L) Quantification of data from (G) (U373MG; 0, 15, 30, 45 and 60 min, $\mathrm{n}=3 ;{ }^{* *} \mathrm{P}<0.01 ;{ }^{* * *} \mathrm{P}<0.001$, ANOVA with post hoc Tukey's test), (I) (T98G; 0, 15, 30, 45 and 60 min, $n=3$; ${ }^{*} \mathrm{P}<0.05$, ANOVA with post hoc Tukey's test), (K) (A172; 0, 15, 30, 45 and 60 min, $\mathrm{n}=3$; ${ }^{*} \mathrm{P}<0.05$, ANOVA with post hoc Tukey's test). (A-C) Scale bar, $200 \mu \mathrm{m}$.

scratching) and $24 \mathrm{~h}$, we acquired images of the wound gap at both time-points and measured the proportion of cells migrated from $0 \mathrm{~h}$ to $24 \mathrm{~h}$ at different PMA concentrations. Subtracting the surface area at $0-24 \mathrm{~h}$ with vehicle treatment 
A U373MG

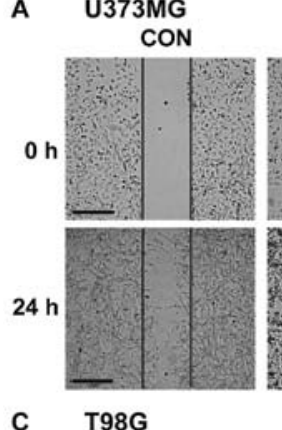

C T98G
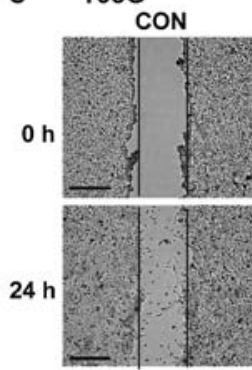

E $\quad$ A172

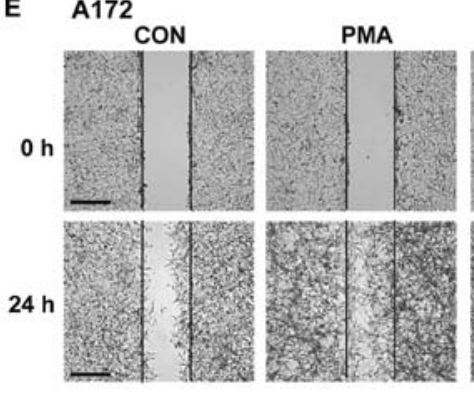

G A172
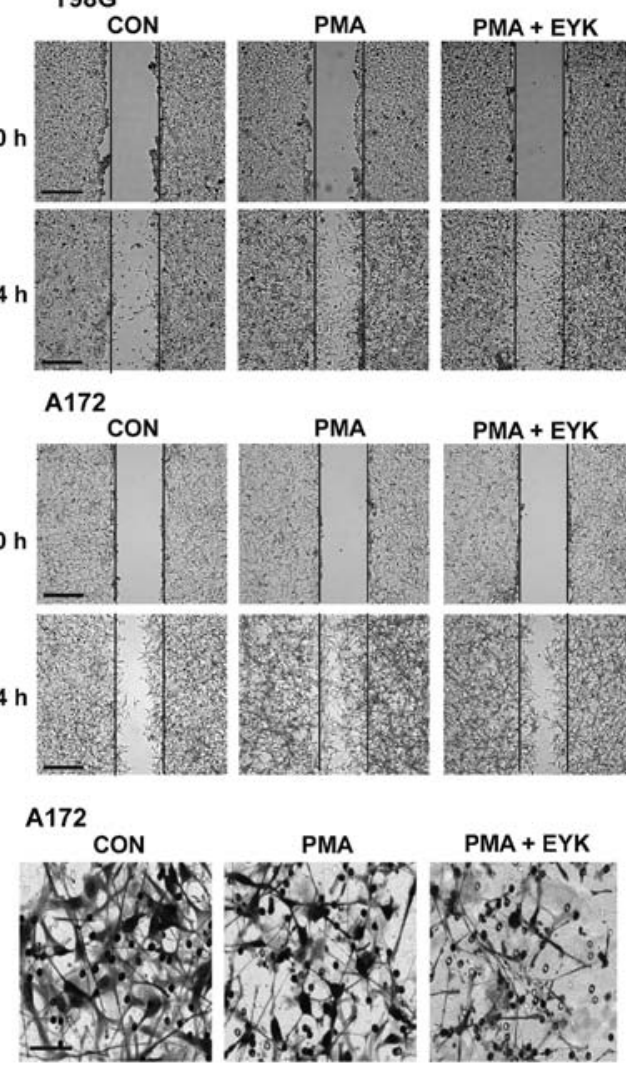

$P M A+E Y K$

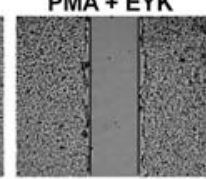

$P M A+E Y K$
$P M A+E Y K$
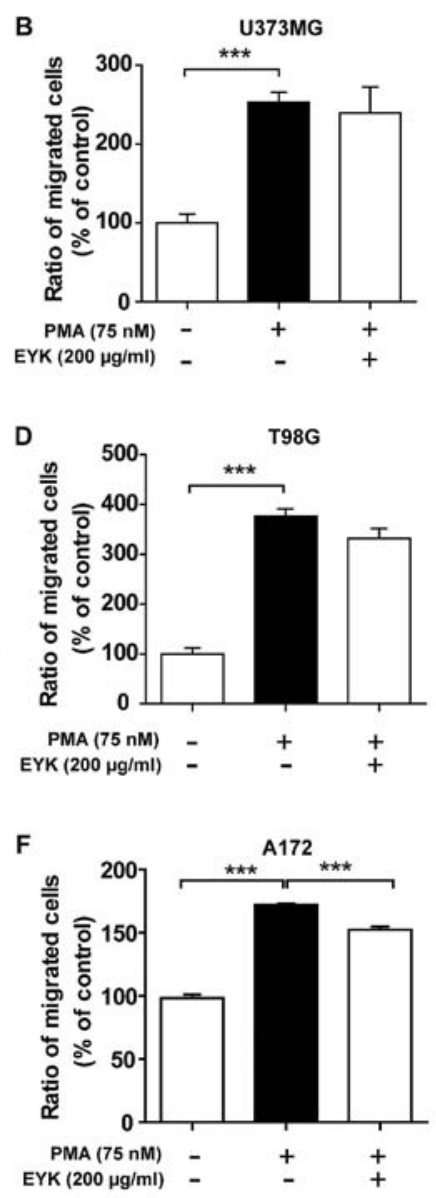

$\mathrm{H}$

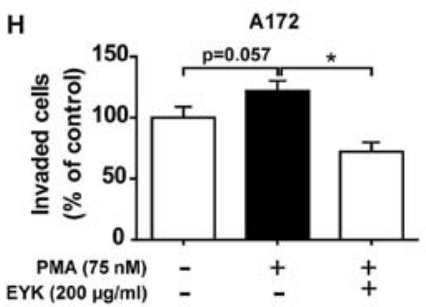

Figure 3. Pre-treatment with PMA and EYK treatment inhibits PMA-induced cell migration and invasion. (A) U373MG, (C) T98G or (E) A172 cell monolayers were scratched with a pipette tip, pre-treated with vehicle or PMA $(75 \mathrm{nM})$ for $45 \mathrm{~min}$, and then treated with vehicle or EYK (200 $\mu \mathrm{g} / \mathrm{ml})$ for $24 \mathrm{~h}$. Images of the wound gap were acquired at $0 \mathrm{~h}$ (i.e., immediately after scratching) and after $24 \mathrm{~h}$. (B, D and F) Quantification of data from (A) (U373MG: con, n=19; PMA, $\mathrm{n}=27$; PMA+EYK, $\mathrm{n}=15 ;{ }^{* * *} \mathrm{P}<0.001$; ANOVA with post hoc Tukey's test), (C) (T98G: con, n=13; PMA, n=18; PMA+EYK, n=10; *** P $<0.001$; ANOVA with post hoc Tukey's test), and (E) (A172: con, $n=26$; PMA, $n=26$; PMA+EYK, $n=28 ;{ }^{* * *} \mathrm{P}<0.001$; ANOVA with post hoc Tukey's test). (G) A172 cells were pre-treated with PMA $(75 \mathrm{nM})$ or vehicle for $45 \mathrm{~min}$, treated with vehicle or EYK $(200 \mu \mathrm{g} / \mathrm{ml})$ for $24 \mathrm{~h}$, and then subjected to Transwell invasion assays. (H) Quantification of data from (G) (A172: con, n=7; PMA, n=7; PMA+EYK, n=7; "P<0.05; ANOVA with post hoc Tukey's test, con vs. PMA, P=0.057; two-tailed t-test). (A, C and E) Scale bar, $200 \mu \mathrm{m}$, and (G) $100 \mu \mathrm{m}$.

were listed as $100 \%$, and difference between the areas at $0-24 \mathrm{~h}$ at various PMA concentrations were compared with vehicle treatment. PMA dramatically increased cell migration relative to the vehicle at all doses tested in U373MG (Fig. 2A and $\mathrm{D}, \mathrm{P}<0.01 ; \mathrm{P}<0.001$; ANOVA with post hoc Tukey's test), T98G (Fig. 2B and E, P<0.001, ANOVA with post hoc Tukey's test), and A172 cells (Fig. $2 \mathrm{C}$ and $\mathrm{F}, \mathrm{P}<0.01, \mathrm{P}<0.001$, ANOVA with post hoc Tukey's test), with an optimal concentration at $75 \mathrm{nM}$ in all three cell lines.

To determine the optimal time for PMA treatment, we treated U373MG, T98G and A172 cells with vehicle or PMA at various times $(15,30,45$ and $60 \mathrm{~min})$ and performed western blotting to detect anti-p-ERK and total ERK, an important signaling for cancer migration (16). PMA significantly increased p-ERK at all time-points in U373MG (Fig. 2G and H, $\mathrm{P}<0.01, \mathrm{P}<0.001$, ANOVA with post hoc Tukey's test), T98G (Fig. 2I and J, P<0.05, ANOVA with post hoc Tukey's test), and A172 cells (Fig. $2 \mathrm{~K}$ and $\mathrm{L}, \mathrm{P}<0.05$, ANOVA with post hoc Tukey's test). Based on our findings and literature, we selected a dose of $75 \mathrm{nM}$ and a duration of 45 min for PMA treatment in the following experiments (15).

To determine whether EYK can alter cell migration in human malignant cells, we performed wound healing assays on U373MG, T98G and A172 cells pre-treated with PMA $(75 \mathrm{nM})$ or vehicle for $45 \mathrm{~min}$, and then treated with EYK $(200 \mu \mathrm{g} / \mathrm{ml})$ or vehicle for $24 \mathrm{~h}$. As expected, PMA alone significantly increased cell migration in all three cell lines (Fig. 3A-F). EYK did not alter PMA-induced cell migration in 

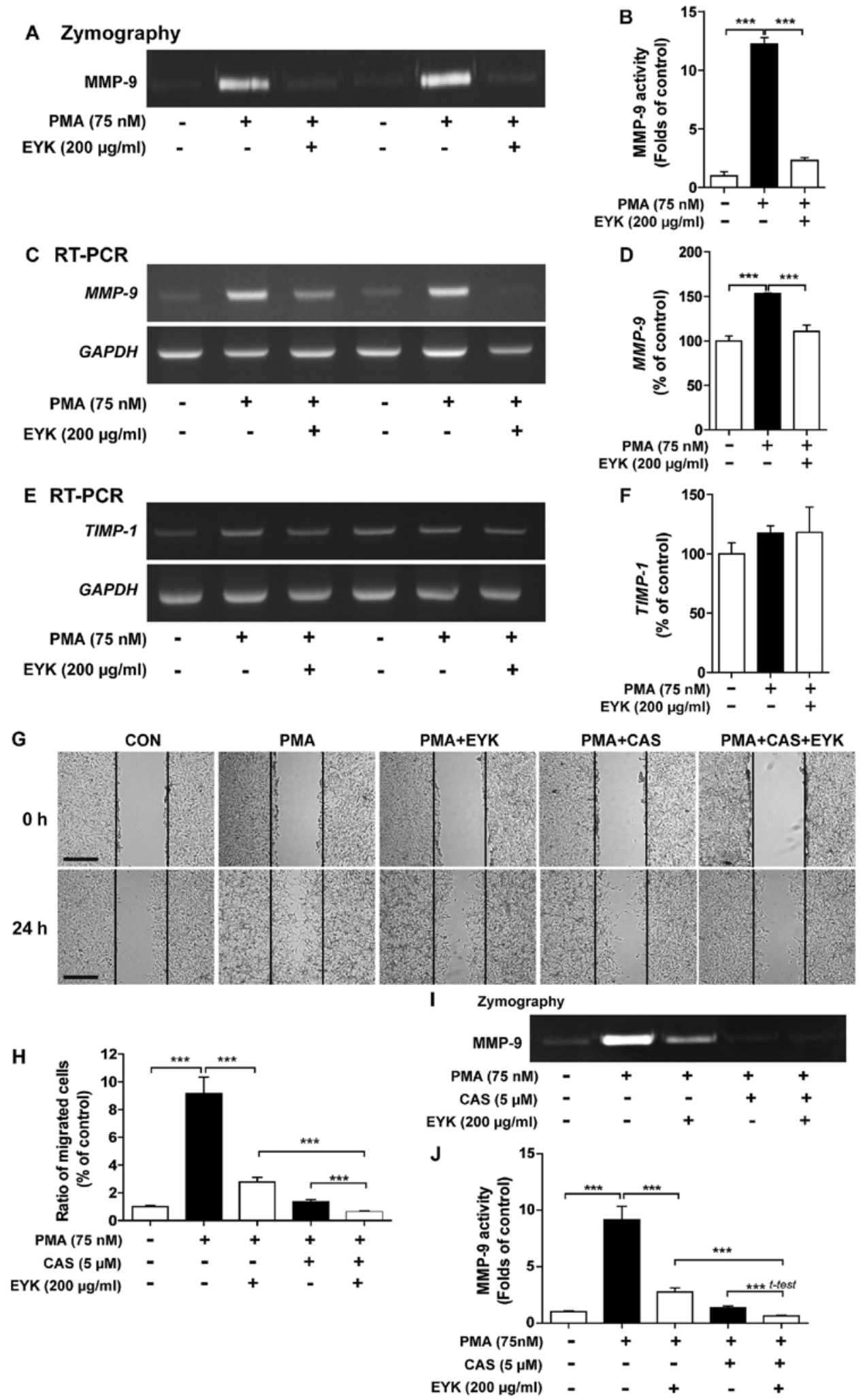

Figure 4. Pre-treatment with PMA followed by EYK treatment decreases MMP-9 activity in A172 cells. (A) A172 cells were pre-treated with vehicle or PMA $(75 \mathrm{nM})$ for $45 \mathrm{~min}$, and then treated with EYK $(200 \mu \mathrm{g} / \mathrm{ml})$ or vehicle for $24 \mathrm{~h}$. After $24 \mathrm{~h}$, gelatin zymography assays were conducted on conditioned medium to measure MMP-9 activity. (B) Quantification of data from A (A172: con, n=6; PMA, n=6; PMA+EYK, n=6; ${ }^{* * *} \mathrm{P}<0.001$; ANOVA with post hoc Tukey's test). (C and E) A172 cells were pre-treated with vehicle or PMA $(75 \mathrm{nM})$ for $45 \mathrm{~min}$ and treated with EYK $(200 \mu \mathrm{g} / \mathrm{ml})$ or vehicle for $24 \mathrm{~h}$. After $24 \mathrm{~h}$, mRNA levels of $M M P-9$ (C), TIMP-1 (E) and GAPDH were measured by RT-PCR. (D and F) Quantification of data from (C) (A172: con, n=8; PMA, n=8; PMA+EYK, $\mathrm{n}=8 ;{ }^{* * *} \mathrm{P}<0.001$; ANOVA with post hoc Tukey's test) and (E) (A172: con, $\mathrm{n}=4$; PMA, $\mathrm{n}=4$; PMA+EYK, $\left.\mathrm{n}=4\right)$. (G) A172 cell monolayers were scratched with a pipette tip, pre-treated with vehicle or PMA $(75 \mathrm{nM})$ for $45 \mathrm{~min}$, treated with vehicle or CAS 1177749-58-4 (5 $\mu \mathrm{M}$, MMP-9 inhibitor) for $1 \mathrm{~h}$, and then treated with vehicle or EYK $(200 \mu \mathrm{g} / \mathrm{ml})$ for $24 \mathrm{~h}$. Images of the wound gap were acquired at $0 \mathrm{~h}$ (i.e., immediately after scratching) and after $24 \mathrm{~h}$. (H) Quantification of data from (G) (A172: con, n=25; PMA, n=25; PMA+EYK, n=28; PMA+CAS, n=40; PMA+CAS+EYK, n=37; ${ }^{* * *} \mathrm{P}<0.001$; ANOVA with post hoc Tukey's test). (I) A172 cells were pre-treated with vehicle or PMA ( $75 \mathrm{nM})$ for $45 \mathrm{~min}$, treated with vehicle or CAS 1177749-58-4 (5 $\mu \mathrm{M}$, MMP-9 inhibitor) for $1 \mathrm{~h}$, and treated with vehicle or EYK $(200 \mu \mathrm{g} / \mathrm{ml})$ for $24 \mathrm{~h}$. After $24 \mathrm{~h}$, gelatin zymography assays were conducted. (J) Quantification of data from I (A172: con, n=28; PMA, n=28; PMA+EYK, n=28; PMA+CAS, n=28; PMA+CAS+EYK, n=28; ${ }^{* * *} \mathrm{P}<0.001$; ANOVA with post hoc Tukey's test, PMA+CAS vs. PMA+CAS+EYK; two-tailed t-test). (G) Scale bar, $200 \mu \mathrm{m}$. 
comparison with PMA in U373MG or T98G cells (Fig. 3A-D, $\mathrm{P}<0.001$; ANOVA with post hoc Tukey's test). By contrast, EYK significantly suppressed PMA-mediated cell migration in A172 cells (Fig. 3E and F, P<0.001; ANOVA with post hoc Tukey's test).

Next, we performed Transwell assays to investigate whether EYK can regulate cell invasion. To this end, A172 cells were pre-treated with PMA or vehicle for $45 \mathrm{~min}$, treated with vehicle or EYK $(200 \mu \mathrm{g} / \mathrm{ml})$ for $24 \mathrm{~h}$, and then subjected to cell invasion assays. PMA increased cell invasion in comparison with vehicle (Fig. $3 \mathrm{G}$ and $\mathrm{H}, \mathrm{P}<0.05$; ANOVA with post hoc Tukey's test, $\mathrm{CON}$ vs. $\mathrm{PMA}, \mathrm{P}=0.057$; two-tailed t-test). However, EYK inhibited PMA-induced cell invasion (Fig. 3G and H). Together, these data indicate that EYK can inhibit PMA-mediated cell migration and invasion, at least in monomorphic malignant human glioma cells.

Pre-treatment with PMA followed by EYK decreased MMP-9 activity in A172 cells. To determine whether EYK regulates activity and expression of MMPs, which are involved in cell migration and invasion $(15,17)$, we pre-treated A172 cells with PMA (75 $\mathrm{nM}$ ) or vehicle for 45 min, treated with EYK $(200 \mu \mathrm{g} / \mathrm{ml})$ or vehicle for $24 \mathrm{~h}$, and then conducted gelatin zymography assays. PMA significantly increased MMP-9 activity compared to vehicle (Fig. $4 \mathrm{~A}$ and $\mathrm{B}, \mathrm{P}<0.001$; ANOVA with post hoc Tukey's test). EYK significantly decreased PMA-induced MMP-9 activity (Fig. 4A and B).

In order to examine the effects of EYK on MMP-9 and TIMP-1 mRNA levels, we conducted RT-PCR under the same conditions as described above. We found that PMA significantly increased $M M P-9$ and TIMP-1 mRNA levels compared to vehicle (Fig. 4C-F). EYK significantly decreased PMA-mediated MMP-9 mRNA levels (Fig. 4C and D, $\mathrm{P}<0.001$; ANOVA with post hoc Tukey's test), but had no effect on TIMP-1 mRNA levels (Fig. 4E and F). These data suggest that EYK can regulate PMA-induced MMP-9 activity as well as its mRNA levels.

We then investigated whether EYK requires MMP-9 activity to alter cell migration. For this purpose, A172 cells were pre-treated with vehicle or PMA $(75 \mathrm{nM})$, treated with CAS1177749-58-4 (an MMP-9 inhibitor, $5 \mu \mathrm{M}$ ) for $1 \mathrm{~h}$, exposed to vehicle or EYK (200 $\mu \mathrm{g} / \mathrm{ml})$ for $24 \mathrm{~h}$, and then subjected to the wound healing assay. Consistent with our findings above, PMA significantly increased cell migration but EYK significantly decreased PMA-induced cell migration (Fig. 4G and H, P<0.001; ANOVA with post hoc Tukey's test). In addition, pretreatment with PMA, MMP-9 inhibitor, and EYK treatment further decreased cell migration compared to treatment with PMA and EYK (Fig. 4G and H). Moreover, we found that treatments with PMA, MMP-9 inhibitor, and EYK significantly reduced MMP-9 activity compared to PMA and EYK treatment (Fig. 4I and J; P<0.001; ANOVA with post hoc Tukey's test, PMA+CAS vs. PMA+CAS+EYK; two-tailed t-test).

EYK significantly decreased PMA-induced NF- $\kappa B$ translocation to the nucleus. A transcriptional factor NF- $\mathrm{KB}$ plays an important role in cell migration and invasion by regulating MMP activity (18). Hence, we initially investigated whether EYK could alter PMA-induced NF- $\mathrm{KB}$ levels in the cytosol vs. the nucleus. For these experiments, A172 cells were pre-treated with PMA (75 $\mathrm{nM}$ ) or vehicle for $45 \mathrm{~min}$, treated with EYK $(200 \mu \mathrm{g} / \mathrm{ml})$ or vehicle for $45 \mathrm{~min}$, and then subjected to subcellular fractionation. PMA treatment showed a trend toward increased $\mathrm{p}-\mathrm{I} \kappa \mathrm{B} \alpha$ and NF- $\mathrm{KB}$ levels, but decreased IкB $\alpha$ levels in the cytosol (Fig. 5A-D; $\mathrm{P}<0.01$; ANOVA with post hoc Tukey's test). EYK did not alter PMA-induced $\mathrm{p}$-I $\kappa \mathrm{B} \alpha$ and I $\mathrm{B} \boldsymbol{\mathrm { B }} \alpha$ levels, but significantly decreased PMA-mediated NF- $\kappa B$ levels in the cytosol (Fig. 5A-D). In addition, EYK did not alter the PMA-induced NF- $\kappa B$ levels in the nucleus (Fig. 5E and F, P<0.01; ANOVA with post hoc Tukey's test).

We then asked whether EYK could alter NF- $\mathrm{kB}$ subcellular localization when administered for longer periods of time. To answer this question, A172 cells were pre-treated with PMA (75 nM) or vehicle for $45 \mathrm{~min}$, treated with EYK $(200 \mu \mathrm{g} / \mathrm{ml})$ or vehicle for $24 \mathrm{~h}$, and then subjected to subcellular fractionation. EYK slightly decreased PMA-induced

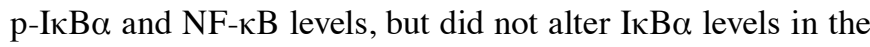
cytosol (Fig. 5G-J, P<0.001; ANOVA with post hoc Tukey's test). In addition, EYK significantly decreased PMA-mediated NF- $\kappa B$ levels in the nucleus (Fig. $5 \mathrm{~K}$ and $\mathrm{L}, \mathrm{P}<0.05 ; \mathrm{P}<0.001$; ANOVA with post hoc Tukey's test).

To examine whether EYK can alter PMA-induced p-NF- $\kappa B$ levels in the nucleus, A172 cells were pre-treated with PMA $(75 \mathrm{nM})$ or vehicle for $45 \mathrm{~min}$, treated with EYK $(200 \mu \mathrm{g} / \mathrm{ml})$ or vehicle for $24 \mathrm{~h}$, and then immunostaining were performed. PMA significantly increased $\mathrm{p}-\mathrm{NF}-\kappa \mathrm{B}$ levels in the nucleus (Fig. 5M and N, P<0.001; ANOVA with post hoc Tukey's test). EYK significantly decreased PMA-induced p-NF- $\kappa B$ levels in the nucleus (Fig. 5M and N). These data suggest that EYK can alter NF- $\mathrm{BB}$ nuclear translocation between subcellular compartments.

EYK suppresses PMA-mediated cell migration via the $N F-\kappa B$ pathway. To determine whether EYK requires NF- $\mathrm{B}$ to suppress cancer cell migration, we performed wound healing assays on A172 cells pre-treated with PMA (75 nM) or vehicle for $45 \mathrm{~min}$, treated with BAY 11-7085 $(10 \mu \mathrm{M}$, a NF- $\kappa B$ inhibitor) or vehicle for $1 \mathrm{~h}$, and then treated with EYK $(200 \mu \mathrm{g} / \mathrm{ml})$ or vehicle for $24 \mathrm{~h}$ (Fig. 6A and B, P<0.05; $\mathrm{P}<0.001$; ANOVA with post hoc Tukey's test). Treatments with PMA, NF- $\mathrm{KB}$ inhibitor, and EYK significantly inhibited cell migration in comparison with treatments with PMA and EYK, suggesting that NF- $\mathrm{KB}$ is necessary for EYK to regulate cell migration.

Next, we examined the effects of EYK on MMP-9 activity by treating cells with PMA and NF- $\mathrm{kB}$ inhibitor and found that inhibition of NF- $\mathrm{KB}$ in combination with EYK treatment further decreased PMA-induced MMP-9 activity in comparison with PMA and EYK treatments (Fig. $6 \mathrm{C}$ and $\mathrm{D}, \mathrm{P}<0.05$; $\mathrm{P}<0.01 ; \mathrm{P}<0.001$; ANOVA with post hoc Tukey's test).

Pre-treatment with EYK and PMA treatment suppresses cell migration. To determine whether pre-treatment with EYK can modulate cell migration, we performed wound healing assays on A172 cells pre-treated with vehicle or EYK $(200 \mu \mathrm{g} / \mathrm{ml})$ for $45 \mathrm{~min}$, treated with PMA $(75 \mathrm{nM})$ or vehicle for $24 \mathrm{~h}$, and then wound healing assays were conducted. PMA significantly increased cancer cell migration, but this effect was suppressed 
A

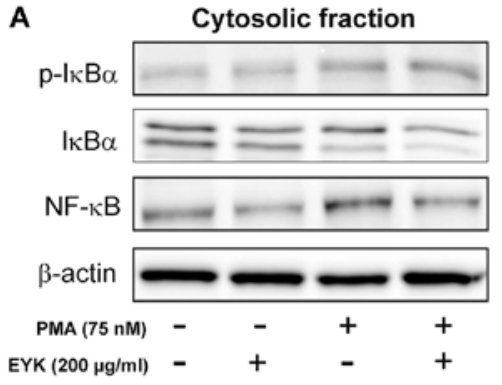

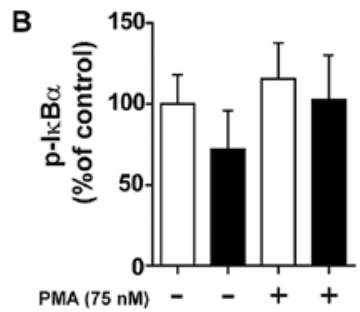

EYK $(200 \mu \mathrm{g} / \mathrm{ml})-+\quad+$
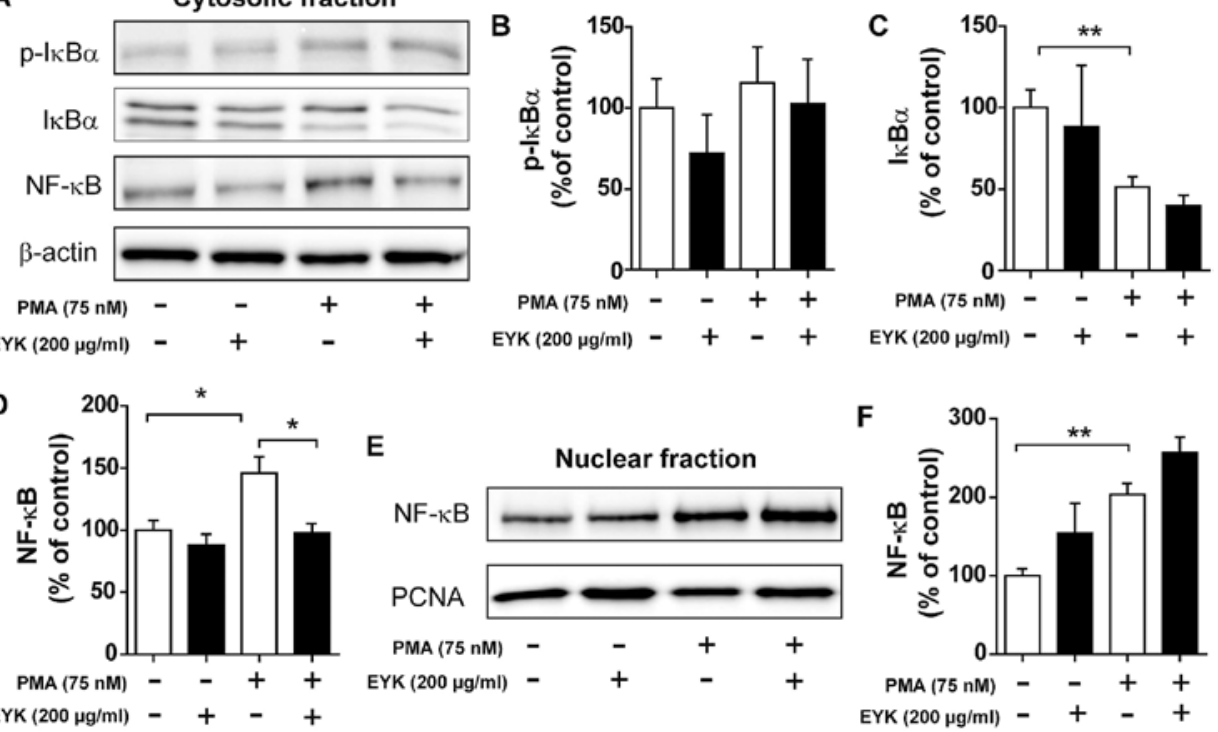

$E$

NF-kB

PCNA

PMA $(75 \mathrm{nM}$

EYK $(200 \mu g / m l)-$

F

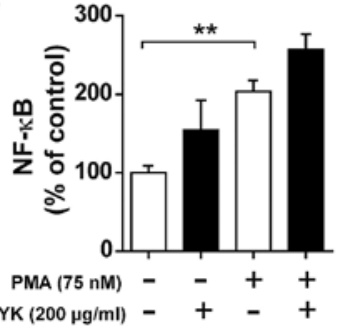

G

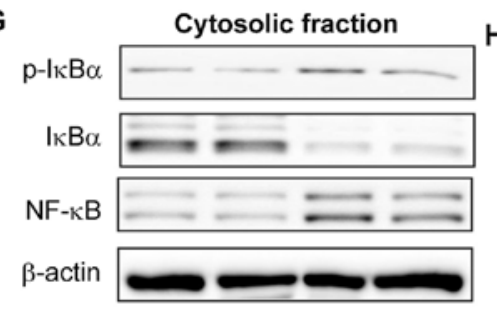

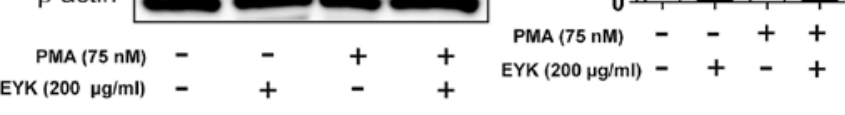

J

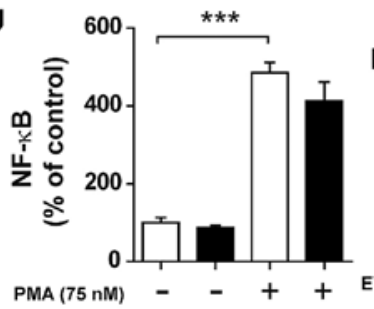

\section{K}

( NFB PCNA

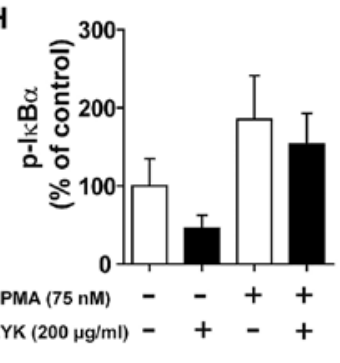

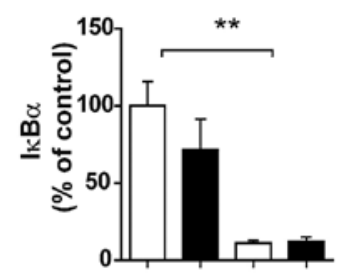

$\operatorname{PMA}(75 \mathrm{nM})-\quad-++$ EYK $(200 \mu \mathrm{g} / \mathrm{ml})-+-+$

L $\quad 500$ ॠ** *

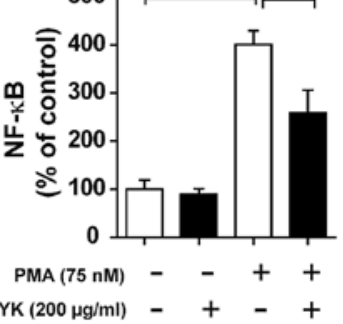

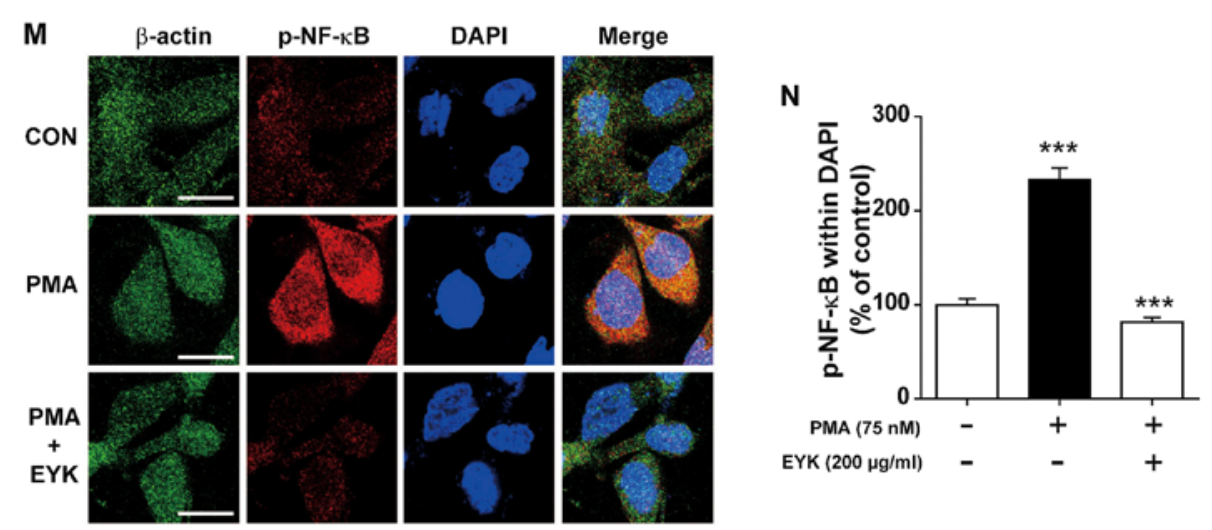

Figure 5. Pre-treatment with PMA followed by EYK treatment decreased NF-kB levels in the nucleus. (A) A172 cells were pre-treated with vehicle or PMA $(75 \mathrm{nM})$ for $45 \mathrm{~min}$, treated with EYK $(200 \mu \mathrm{g} / \mathrm{ml})$ or vehicle for $45 \mathrm{~min}$, and then subjected to subcellular fractionation (nucleus vs. cytosol). Western blotting was performed on the cytosolic fraction using antibodies against $\mathrm{p}$-І $\mathrm{KB} \alpha, \mathrm{I} \kappa \mathrm{B} \alpha, \mathrm{NF}-\kappa \mathrm{B}$ and $\beta$-actin. (B-D) Quantification of data from A (A172: con, n=5; EYK, $n=2$; PMA, $n=5$; PMA+EYK, $n=5 ;{ }^{*} \mathrm{P}<0.05$; ${ }^{* *} \mathrm{P}<0.01$; ANOVA with post hoc Tukey's test). (E) Western blotting was performed on the nuclear fraction using antibodies against NF- $\mathrm{KB}$ and PCNA. (F) Quantification of data from E (A172: con, n=5; EYK, n=2; PMA, n=5; PMA+EYK, n=5; ${ }^{* *} \mathrm{P}<0.01$; ANOVA with post hoc Tukey's test). (G) A172 cells were pre-treated with vehicle or PMA ( $75 \mathrm{nM})$ for $45 \mathrm{~min}$, treated with EYK (200 $\mu \mathrm{g} / \mathrm{ml})$ or vehicle for $24 \mathrm{~h}$, and then subjected to subcellular fractionation (nucleus vs. cytosol). Western blotting was performed on the cytosolic fraction using antibodies against p-IкB $\alpha$,

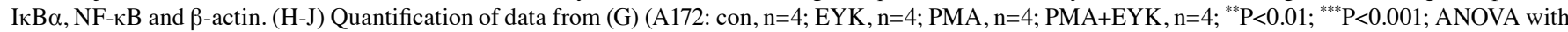
post hoc Tukey's test). (K) Western blotting was performed on the nuclear fraction using antibodies against NF- $\mathrm{kB}$ and PCNA. (L) Quantification of data from (K) (A172: con, n=4; EYK, n=4; PMA, n=4; PMA+EYK, $n=4 ;{ }^{*} \mathrm{P}<0.05 ;{ }^{* * *} \mathrm{P}<0.001$; ANOVA with post hoc Tukey's test). (M) A172 cells were pre-treated with vehicle or PMA $(75 \mathrm{nM})$ for $45 \mathrm{~min}$, treated with EYK $(200 \mu \mathrm{g} / \mathrm{ml})$ or vehicle for $24 \mathrm{~h}$, and immunostaing were performed using antibodies against p-NF- $\mathrm{kB}$ and $\beta$-actin. (N) Quantification of data from M (A172: con, $\mathrm{n}=63$ cells; PMA, $\mathrm{n}=61$ cells; PMA+EYK, $\mathrm{n}=68$ cells; ${ }^{* * * *} \mathrm{P}<0.01$; ANOVA with post hoc Tukey's test). (M) Scale bar, $20 \mu \mathrm{m}$. 


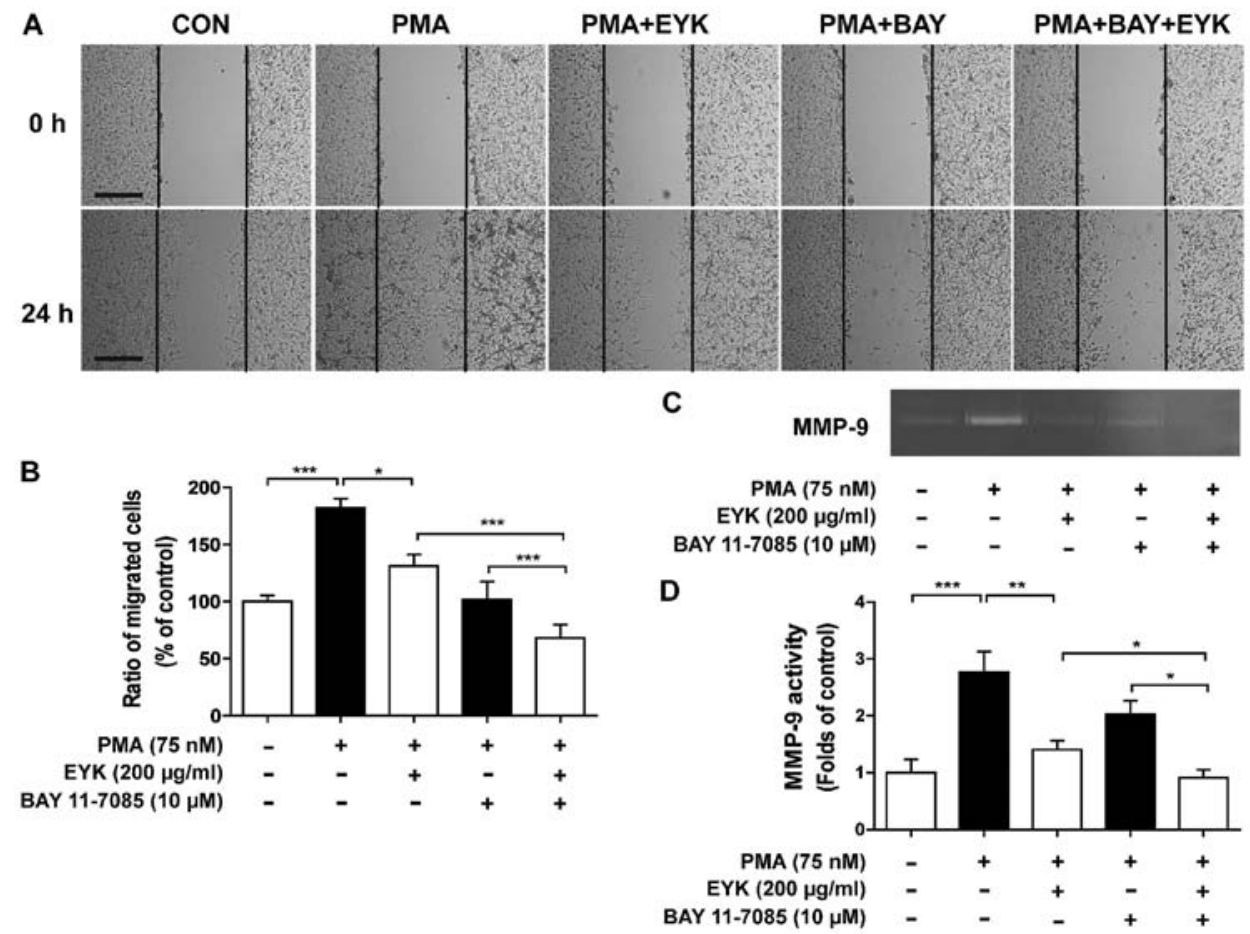

Figure 6. Pre-treatment with PMA and EYK treatment inhibits PMA-induced cancer cell migration via NF- $\mathrm{kB}$. (A) A172 cell monolayers were scratched with a scraper, pre-treated with PMA (75 nM) or vehicle for $45 \mathrm{~min}$, treated with BAY 11-7085 (NF-kB inhibitor, $10 \mu \mathrm{M}$ ) or vehicle for $1 \mathrm{~h}$, and then treated with EYK $(200 \mu \mathrm{g} / \mathrm{ml})$ or vehicle for $24 \mathrm{~h}$. Images of the wound gap were acquired at $0 \mathrm{~h}$ (i.e., immediately after scratching) and after $24 \mathrm{~h}$. (B) Quantification of data from (A) (A172: con, $n=20$; PMA, n=17; PMA+EYK, $n=17$; PMA+BAY, n=17; PMA+BAY+EYK, $n=21 ;{ }^{*} \mathrm{P}<0.05$; ${ }^{* * *} \mathrm{P}<0.001$; ANOVA with post hoc Tukey's test).

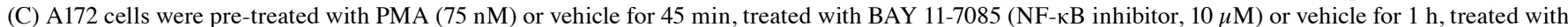
EYK $(200 \mathrm{mg} / \mathrm{ml})$ or vehicle for $24 \mathrm{~h}$, and then subjected to gelatin zymography. (D) Quantification of data from (C) (A172: con, n=8; PMA, n=8; PMA+EYK, $\mathrm{n}=8$; PMA+BAY, n=8; PMA+BAY+EYK, $\mathrm{n}=8 ;{ }^{*} \mathrm{P}<0.05 ;{ }^{* *} \mathrm{P}<0.01 ;{ }^{* * * *} \mathrm{P}<0.001$; ANOVA with post hoc Tukey's test). (A) Scale bar, $200 \mu \mathrm{m}$.

by pre-treatment with EYK (Fig. 7A and B, P<0.001; ANOVA with post hoc Tukey's test).

Next, we performed the Transwell assays to investigate the effects of pre-treatment with EYK on cell invasion and found that PMA significantly increased cell invasion while pre-treatment with EYK significantly inhibited PMA-induced cell invasion (Fig. 7C and D, $\mathrm{P}<0.05$; ANOVA with post hoc Tukey's test).

We then investigated whether pre-treatment with EYK could alter MMP-9 activity and found that pre-treatment with EYK significantly decreased PMA-induced MMP-9 activity (Fig. 7E and F, P<0.001; ANOVA with post hoc Tukey's test). Moreover, pre-treatment with EYK significantly decreased PMA-induced MMP-9 mRNA levels, but had no effect on TIMP-1 mRNA levels (Fig. 7G-I, $\mathrm{P}<0.05$; $\mathrm{P}<0.001$; ANOVA with post hoc Tukey's test).

Pre-treatment with EYK alters cell migration through $N F-\kappa B$ pathway. To determine whether pre-treatment with EYK can regulate PMA-induced $\mathrm{NF}-\kappa \mathrm{B}$ subcellular translocation, we pre-treated A172 cells with EYK $(200 \mu \mathrm{g} / \mathrm{ml})$ or vehicle for $45 \mathrm{~min}$, treated with PMA (75 $\mathrm{nM})$ or vehicle for $24 \mathrm{~h}$, and then performed subcellular fractionation. Pre-treatment with EYK followed by PMA treatment showed a trend toward decreased $\mathrm{p}-\mathrm{I} \kappa \mathrm{B} \alpha$ levels and did not alter I $\mathrm{B} \alpha$ and $\mathrm{NF}-\kappa \mathrm{B}$ levels in the cytosol (Fig. 8A-D, P<0.05; ANOVA with post hoc Tukey's test). In the nuclear fraction, pre-treatment with EYK significantly decreased PMA-induced NF- $\kappa$ B levels (Fig. 8E and F, $\mathrm{P}<0.01 ; \mathrm{P}<0.001$, ANOVA with post hoc
Tukey's test). Moreover, pre-treatment with EYK significantly decreased PMA-induced $\mathrm{p}-\mathrm{NF}-\kappa \mathrm{B}$ levels in the nucleus (Fig. 8G and H, P<0.001; ANOVA with post hoc Tukey's test).

We then investigated whether pre-treatment with EYK could alter cell migration via NF- $\kappa \mathrm{B}$ pathways. To test this, we performed wound healing assays on A172 cells pre-treated with vehicle or BAY11-7085 (10 $\mu \mathrm{M}$, an NF- $\kappa \mathrm{B}$ inhibitor) for $1 \mathrm{~h}$, treated with EYK $(200 \mu \mathrm{g} / \mathrm{ml})$ or vehicle for $45 \mathrm{~min}$, and then treated with PMA $75 \mathrm{nM}$ ) or vehicle for $24 \mathrm{~h}$. Pre-treatment with EYK decreased PMA-induced cell migration (Fig. 8I and J, P<0.05; $\mathrm{P}<0.001$, ANOVA with post hoc Tukey's test; EYK+PMA vs. BAY+EYK+PMA, twotailed t-test). In addition, pre-treatment with $N F-\kappa B$ inhibitor followed by treatments with EYK and PMA further inhibited cell migration in comparison with treatments with EYK and PMA (Fig. 8I and J). Based on these findings, we conclude that EYK could be used as a drug to prevent cancer cell migration by decreasing the nuclear localization of NF- $\kappa$ B and MMP-9 activity in A172 cells (Fig. 8K).

\section{Discussion}

Glioblastoma multiforme (GBM) is characterized by its aggressive cell proliferation and invasive infiltration into the surrounding brain tissue (19), and these features are associated with very poor prognosis (20). Temozolomide (TMZ) in combination with radiation therapy is the typical chemotherapy used to treat GBM (21). However, this approach has several problems, including drug resistance and induction of 

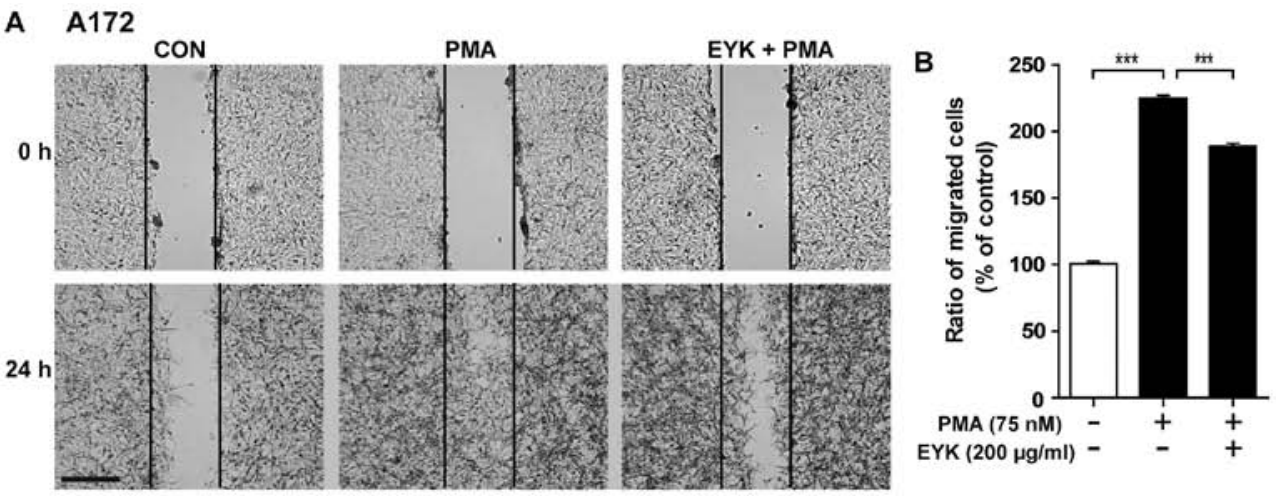

C A172
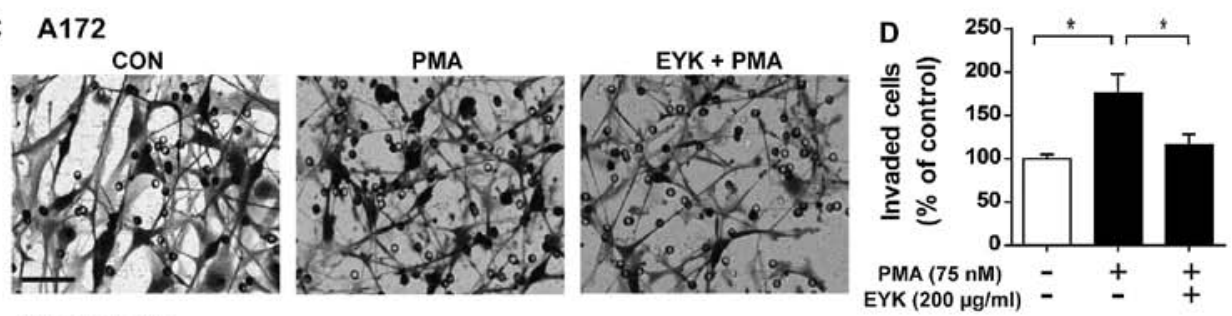

E Zymogrphy
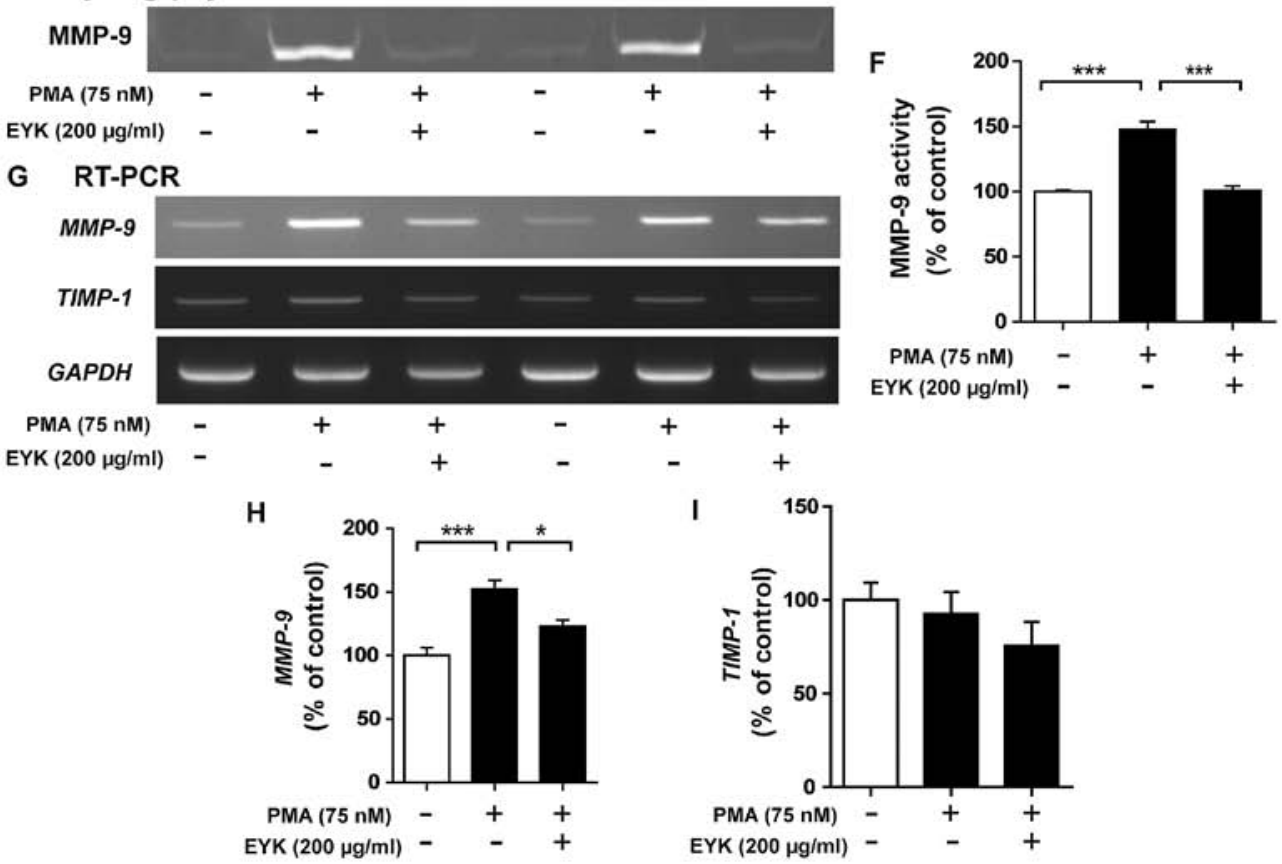

Figure 7. Pre-treatment with EYK and PMA inhibits cancer cell migration and invasion in A172 cells. (A) A172 cell monolayers were scratched with a pipette tip and immediately imaged $(0 \mathrm{~h})$, pre-treated with vehicle or EYK $(200 \mu \mathrm{g} / \mathrm{ml})$ for $45 \mathrm{~min}$, and then treated with vehicle or PMA $(75 \mathrm{nM})$ for $24 \mathrm{~h}$. Images of the wound gap were acquired at $0 \mathrm{~h}$ (i.e., immediately after scratching) and after $24 \mathrm{~h}$. (B) Quantification of data from (A) (A172: con, n=23; PMA, n=31; PMA+EYK, n=35; ${ }^{* * *} \mathrm{P}<0.001$; ANOVA with post hoc Tukey's test). (C) A172 cells were pre-treated with vehicle or EYK (200 $\left.\mu \mathrm{g} / \mathrm{ml}\right)$ for 45 min, and then treated with vehicle or PMA $(75 \mathrm{nM})$ for $24 \mathrm{~h}$. After $24 \mathrm{~h}$, Transwell invasion assays were conducted. (D) Quantification of data from (C) (A172: con, $\mathrm{n}=4$; PMA, n=4; PMA+EYK, n=4; ${ }^{*} \mathrm{P}<0.05$; ANOVA with post hoc Tukey's test). (E) A172 cells were pre-treated with EYK (200 $\left.\mu \mathrm{g} / \mathrm{ml}\right)$ or vehicle for 45 min, and treated with vehicle or PMA $(75 \mathrm{nM})$ for $24 \mathrm{~h}$, and then a gelatin zymography assay was conducted on conditioned medium to measure MMP-9 activity. (F) Quantification of data from (E) (A172: con, n=4; PMA, n=4; PMA+EYK, n=4; ${ }^{* * *} \mathrm{P}<0.001$; ANOVA with post hoc Tukey's test). (G) A172 cells were pretreated with vehicle or EYK $(200 \mu \mathrm{g} / \mathrm{ml})$ for $45 \mathrm{~min}$, and then treated with PMA (75 $\mathrm{nM})$ or vehicle for $24 \mathrm{~h}$. mRNA levels of $M M P-9, T I M P 1$ and $G A P D H$ were measured by RT-PCR. (H and I) Quantification of data from (G) (MMP-9: con, n=8; PMA, n=8; PMA+EYK, n=8; ${ }^{*}<0.05 ;{ }^{* * *} \mathrm{P}<0.001 ;$ ANOVA with post hoc Tukey's test; TIMP1: con, n=4; PMA, n=4; PMA+EYK, n=4). (A) Scale bar, $200 \mu \mathrm{m}$ and (C) $100 \mu \mathrm{m}$.

proliferation and metastasis (21-23). Therefore, it is necessary to develop a novel antitumor agent in order to successfully treat GBM.

In the present study, we discovered that EYK inhibitsmonomorphic malignant human glioma cell migration and invasion by downregulating MMP-9 activity and nuclear localization of NF- $\mathrm{KB}$, the transcription factor primarily responsible for expression of MMP-9. Several studies have demonstrated that EYK has antitumor effects including reduction of drug resistance-causing gene mutations in lung cancer cells (24), induction of apoptosis in human prostate cancer cells (5) and non-small cell lung cancer (6), and downregulation of cell proliferation in osteosarcoma cells (25). However, this is the first study to demonstrate the ability of 

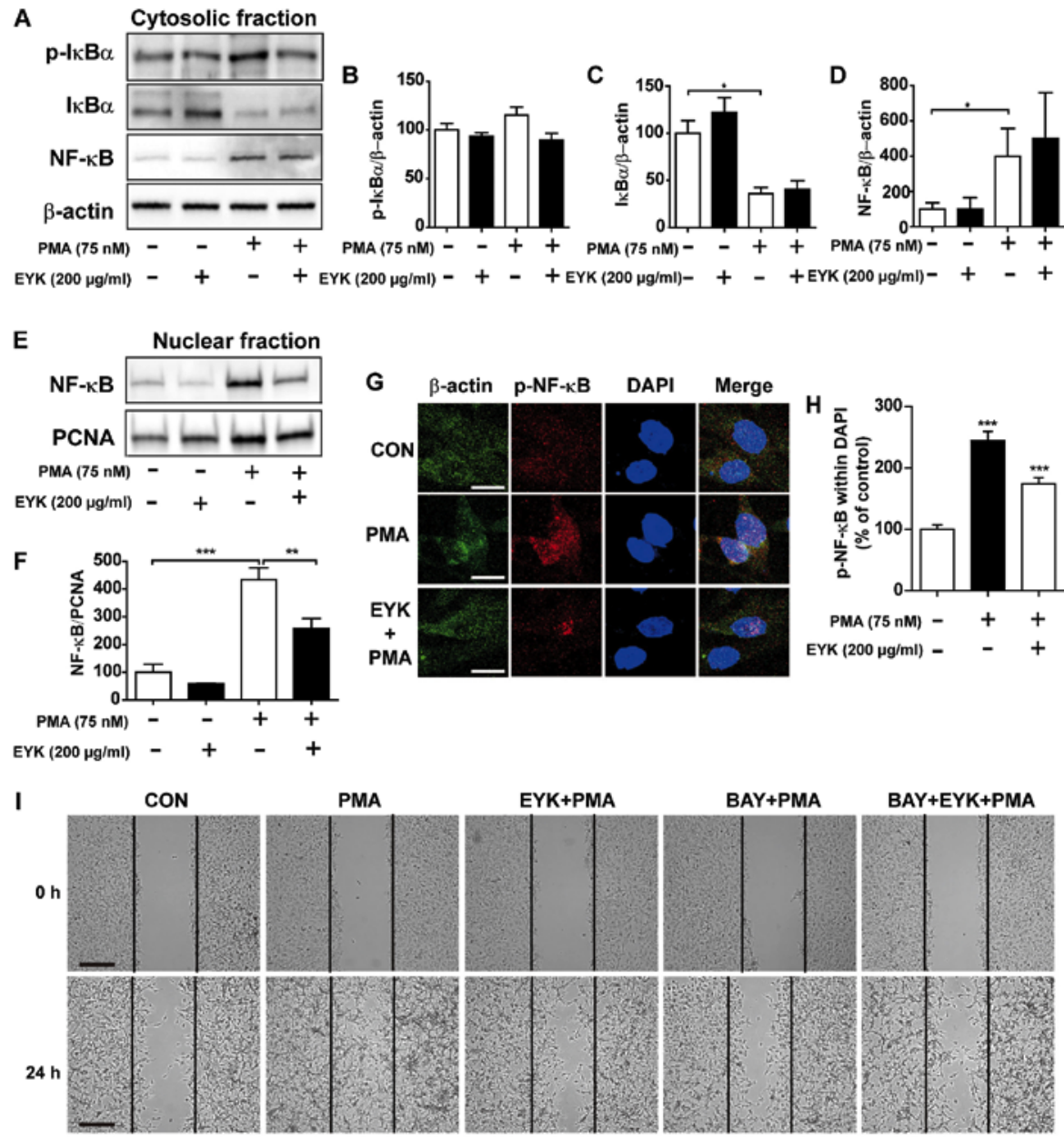

PMA

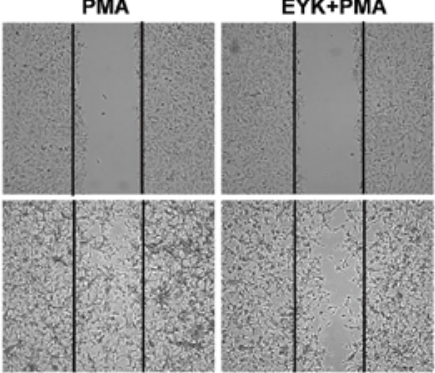

BAY+PMA

BAY+EYK+PMA
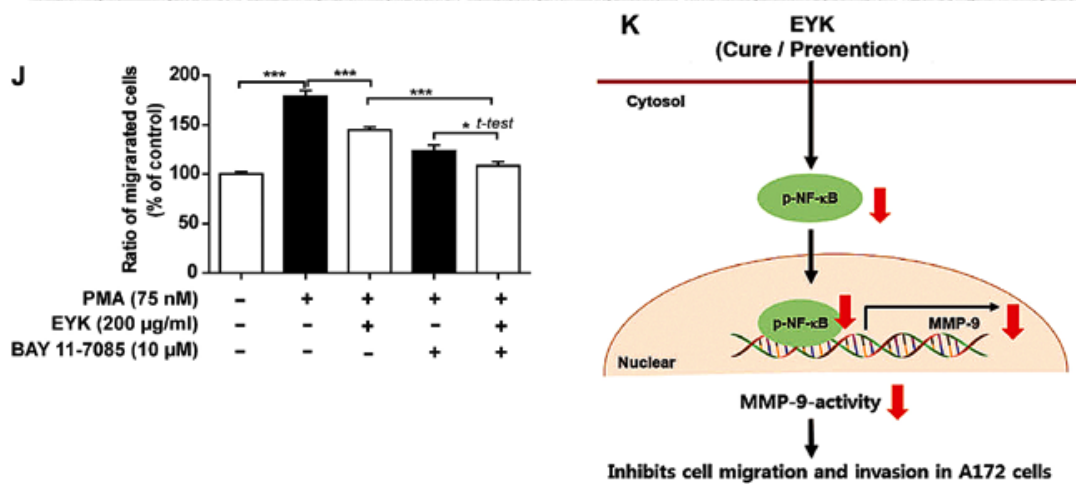

Figure 8. Pre-treatment with EYK and PMA decreases translocation of NF- $\kappa$ B to the nucleus. A172 cells were pre-treated with EYK (200 $\mu$ g/ml) or vehicle for $45 \mathrm{~min}$, treated with vehicle or PMA $(75 \mathrm{nM})$ for $24 \mathrm{~h}$ and subjected to subcellular fractionation (nucleus vs. cytosol). (A) Western blotting was performed on the cytosolic fraction using antibodies against $\mathrm{p}-\mathrm{I} \kappa \mathrm{B} \alpha, \mathrm{I} \kappa \mathrm{B} \alpha, \mathrm{NF}-\kappa \mathrm{B}$ and $\beta$-actin. (B-D) Quantification of data from (A) (A172: con, $\mathrm{n}=4$; EYK, $\mathrm{n}=4$; PMA, $\mathrm{n}=4$; EYK+PMA, $\mathrm{n}=4 ;{ }^{*} \mathrm{P}<0.05$; ANOVA with post hoc Tukey's test). (E) Western blotting was performed on the nuclear fraction using antibodies against NF- $\kappa$ B and PCNA. (F) Quantification of data from (E) (A172: con, n=4; EYK, n=4; PMA, n=4; EYK+PMA, $n=4 ;{ }^{* *} \mathrm{P}<0.01 ;{ }^{* * *} \mathrm{P}<0.001, \mathrm{ANOVA}$ with post hoc Tukey's test). (G) A172 cells were pre-treated with EYK $(200 \mu \mathrm{g} / \mathrm{ml})$ or vehicle for $45 \mathrm{~min}$, treated with vehicle or PMA (75 nM) for $24 \mathrm{~h}$, and immunostaing were performed using antibodies against $\mathrm{p}-\mathrm{NF}-\kappa \mathrm{B}$ and $\beta$-actin. $(\mathrm{H})$ Quantification of data from (G) (A172: con, $\mathrm{n}=126$ cells; PMA, $\mathrm{n}=106$ cells; PMA+EYK, $\mathrm{n}=122$ cells; ${ }^{* * * *} \mathrm{P}<0.001$; ANOVA with post hoc Tukey's test). (I) A172 cell monolayers were scratched with a scraper, pre-treated with vehicle or BAY $11-7085$ $(10 \mu \mathrm{M}, \mathrm{NF}-\kappa \mathrm{B}$ inhibitor) for $1 \mathrm{~h}$, treated with vehicle or EYK $(200 \mu \mathrm{g} / \mathrm{ml})$ for $45 \mathrm{~min}$, and then treated with PMA (75 nM) or vehicle for $24 \mathrm{~h}$. Images of the wound gap were acquired at 0 h (i.e., immediately after scratching) and after 24 h. (J) Quantification of data from (I) (A172: con, n=68; PMA, n=53; EYK+PMA, n=69; BAY+EYK, n=45; BAY+EYK+PMA, n=58; ${ }^{*}>0.05 ;{ }^{* * *} \mathrm{P}<0.001$, ANOVA with post hoc Tukey's test; EYK+PMA vs. BAY+EYK+PMA, two-tailed t-test). (K) Schematic model of suppression of brain cancer cell migration and invasion by EYK. (G) Scale bar, $20 \mu \mathrm{m}$ and (I) $200 \mu \mathrm{m}$.

EYK to inhibit brain cancer cell migration and invasion in human malignant cells.

Cancer cell migration and invasion are the main biological characteristics associated with tumor malignancy (26). In a previous study of Epimedium species, icaritin, a bioactive compound in Epimedium extract, inhibited adhesion, migra- tion and invasion of glioblastoma cells via downregulation of extracellular matrix (ECM) and MMPs mediated by the PTEN/ AKT/HIF-1a pathway (27). In addition, consistently with those previously published results, our present findings demonstrated that pre-treatment with PMA followed by EYK treatment effectively inhibited migration and invasion (Fig. 3) in A172 
cells, but not in two other cell lines, T98G and U373MG. A172 cells are monomorphic and fibroblast-like whereas T98G cells are polymorphic, fibroblast-like and polygonal (28). U373MG cells have pleomorphic features (29). Thus, EYK may selectively alter cell migration and invasion in specific cell types of human brain cancer cells. Indeed, we confirmed that cell migration and invasion were inhibited when EYK was used as a pre-treatment prior to PMA exposure (Fig. 7).

Degradation of ECM is an important process in cancer cell migration and invasion (30). MMPs induce cell migration and invasion by degrading ECM proteins on and around surrounding normal brain tissue (31). One of the MMPs, MMP-9, is overexpressed in experimental glioma models and brain tumor patient tissue samples (32), and plays a major role in invasive infiltration and migration of brain cancer cells $(31,33)$. Accordingly, downregulation of MMP-9 levels prevents tumor growth and invasion in glioblastoma cells lines (34). Quercetin, one of the elements of EYK, inhibits expression of MMP-9 via the AKT/ERK signaling pathway in human glioma cells (35). Our results showed that pre-treatment with PMA followed by EYK treatment dramatically downregulated PMA-induced MMP-9 activity and its mRNA levels in A172 cells (Fig. 4). These results were confirmed in wound healing assays and gelatin zymography assays by treating with CAS 1177749-58-4, MMP-9 inhibitor. Similar to our findings shown in Fig. 4, pre-treatment with EYK and PMA inhibited MMP-9 activity compared to PMA treatment (Fig. 7).

Regulation of MMP-9 is the major anti-oncogenic effect of TIMP-1 (tissue inhibitor of metalloproteinases), an endogenous inhibitor. For instance, B16F10 melanoma-expressing-mice followed by injection of recombinant TIMP-1 decreases pulmonary metastases (36). Hence, we investigated whether EYK regulates MMP-9 activity directly or by modulating levels of TIMP-1. To this end, we asked whether EYK affects TIMP-1 mRNA levels. In this study, neither pre-treatment with PMA followed by EYK nor exposure to the compounds in the opposite order altered TIMP-1 mRNA levels (Figs. 4 and 7). Therefore, we concluded that EYK directly regulates MMP-9 activity to alter cancer cell migration.

Mitrogen-activated protein kinases (MAPK) including ERK, JNK and p38 are involved in cancer cell migration and invasion (37-40) and regulate MMP-9 activity and its expression (41). Notably, we found that PMA in combination with EYK did not alter phosphorylation of ERK, JNK, or p38 (data not shown). We then examined another potential signaling pathways, focal adhesion kinase (FAK) signaling, that are targeted by EYK to regulate cancer cell migration. It is well-established that FAK signaling plays an important role in cancer cell migration as well as invasion (42). For these reasons, we investigated whether EYK can modulate FAK signaling pathway and found that treatment with PMA and EYK in either temporal order did not alter the phosphorylation of FAK (data not shown). Therefore, we concluded that EYK inhibits cell migration independent of PMA-induced MAP kinases and FAK signaling.

To elucidate the molecular mechanism by which EYK inhibits human brain cancer cell migration and invasion, we examined the effect of EYK on NF-KB subcellular localization, which is primarily responsible for regulating MMP-9 expression. In addition, NF- $\mathrm{KB}$ activation contributes to
PMA-induced MMP-9 activity and glioma cell migration (18). In this study, pre- or post-treatment with EYK decreased PMA-mediated nuclear levels of NF-кB (Figs. 5 and 8). Surprisingly, our results indicated that EYK mainly affects nuclear levels of NF- $\kappa B$ without changing the levels of I $\mathrm{B} \alpha$, a cellular inhibitor of NF- $\kappa B$. Thus, EYK may directly regulate subcellular localization of NF- $\mathrm{KB}$ or modulate its translocation to the nucleus via an unknown inhibitory factor, thereby altering cancer cell migration. Accordingly, future studies should further investigate the molecular mechanism underlying regulation of NF- $\mathrm{BB}$ by EYK in monomorphic malignant human glioma cells.

In summary, this study provides for the first time demonstration that EYK exerts its anticancer effect in monomorphic human glioblastoma by inhibiting MMP-9 activity, mediated by a reduction in nuclear localization of NF- $\mathrm{kB}$. This effect could be achieved by pre-treating with PMA followed by EYK treatment (as a cure condition) or by pre-treating with EYK followed by PMA exposure (as a prevention condition) (Fig. 8K). Taken together, our results suggest that EYK could be used as a drug for the cure and prevention of monomorphic malignant human glioma.

\section{Acknowledgements}

The present study was supported by the KBRI Basic Research Program through the Korea Brain Research Institute funded by the Ministry of Science, ICT, \& Future Planning [grant number: 17-BR-03] (H.S.H.), by the National Research Foundation of the Korean government (H.S.H., grant no. 2016R1A2B4011393) and BH community. This study was supported by the Korea Institute of Oriental Medicine (KIOM) funded by the Ministry of Science, ICT,\& Future Planning (MISP) (grant no. K17281). The authors declare no competing financial interests. Bright-field microscopy (Carl Zeiss) data were acquired in the Advanced Neural Imaging Center at the Korea Brain Research Institute (KBRI). We used an English language service-BIOEDIT (https://www.bioedit.com) to prepare our manuscript. We thank So Yeon Koo for writing, editing and valuable comments in our manuscript.

\section{References}

1. Jiang F, Wang XL, Wang NL and Yao XS: Two new flavonol glycosides from Epimedium koreanum Nakai. J Asian Nat Prod Res 11: 401-409, 2009.

2. Xu CQ, Liu BJ, Wu JF, Xu YC, Duan XH, Cao YX and Dong JC: Icariin attenuates LPS-induced acute inflammatory responses: Involvement of PI3K/Akt and NF-kappaB signaling pathway. Eur J Pharmacol 642: 146-153, 2010.

3. Zhang L, Shen C, Chu J,Zhang R, Li Y and Li L: Icariin decreases the expression of APP and BACE- 1 and reduces the $\beta$-amyloid burden in an APP transgenic mouse model of Alzheimer's disease. Int J Biol Sci 10: 181-191, 2014.

4. Han YY, Song MY, Hwang MS, Hwang JH, Park YK and JungHW: Epimedium koreanum Nakai and its main constituent icariin suppress lipid accumulation during adipocyte differentiation of 3T3-L1 preadipocytes. Chin J Nat Med 14: 671-676, 2016.

5. Lee KS, Lee HJ, Ahn KS, Kim SH, Nam D, Kim DK, Choi DY, Ahn KS, Lu J and Kim SH: Cyclooxygenase-2/prostaglandin E2 pathway mediates icariside II induced apoptosis in human PC-3 prostate cancer cells. Cancer Lett 280: 93-100, 2009.

6. Song J, Shu L, Zhang Z, Tan X, Sun E, Jin X, Chen Y and Jia X: Reactive oxygen species-mediated mitochondrial pathway is involved in Baohuoside I-induced apoptosis in human non-small cell lung cancer. Chem Biol Interact 199: 9-17, 2012. 
7. Cho WK, Kim H, Choi YJ, Yim NH, Yang HJ and Ma JY: Epimedium koreanum Nakai water extract exhibits antiviral activity against porcine epidermic diarrhea virus in vitro and in vivo. Evid Based Complement Alternat Med 2012: 985151, 2012.

8. Kang SH, Jeong SJ, Kim SH, Kim JH, Jung JH, Koh W, Kim JH, Kim DK, Chen CY and Kim SH: Icariside II induces apoptosis in U937 acute myeloid leukemia cells: Role of inactivation of STAT3-related signaling. PLoS One 7: e28706, 2012.

9. Chung BH, Kim JD, Kim CK, Kim JH, Won MH, Lee HS, Dong MS, Ha KS, Kwon YG and Kim YM: Icariin stimulates angiogenesis by activating the MEK/ERK- and PI3K/Akt/eNOSdependent signal pathways in human endothelial cells. Biochem Biophys Res Commun 376: 404-408, 2008.

10. Zhang J, Stevens MF and Bradshaw TD: Temozolomide: Mechanisms of action, repair and resistance. Curr Mol Pharmacol 5: 102-114, 2012

11. Johannessen TC and Bjerkvig R: Molecular mechanisms of temozolomide resistance in glioblastoma multiforme. Expert Rev Anticancer Ther 12: 635-642, 2012.

12. Munoz JL, Rodriguez-Cruz V, Greco SJ, Ramkissoon SH, Ligon KL and Rameshwar P: Temozolomide resistance in glioblastoma cells occurs partly through epidermal growth factor receptor-mediated induction of connexin 43. Cell Death Dis 5 e1145, 2014.

13. Armstrong TS, Cao Y, Scheurer ME, Vera-Bolaños E, Manning R, Okcu MF, Bondy M, Zhou R and Gilbert MR: Risk analysis of severe myelotoxicity with temozolomide: The effects of clinical and genetic factors. Neuro Oncol 11: 825-832, 2009.

14. Nam JH, Cho HJ, Kang H, Lee JY, Jung M, Chang YC, KimK and Hoe HS: A Mercaptoacetamide-based class II histone deacetylase inhibitor suppresses cell migration and invasion in monomorphic malignant human glioma cells by inhibiting FAK/ STAT3 Signaling. J Cell Biochem: May 12, 2017 (Epub ahead of print). doi: $10.1002 / \mathrm{jcb} .26133$

15. Cho HJ, Kang JH, Kwak JY, Lee TS, Lee IS, Park NG, Nakajima H, Magae J and Chang YC: Ascofuranone suppresses PMA-mediated matrix metalloproteinase-9 gene activation through the Ras/Raf/MEK/ERK- and Ap1-dependent mechanisms. Carcinogenesis 28: 1104-1110, 2007.

16. Chen H, Zhu G, Li Y, Padia RN, Dong Z, Pan ZK, Liu K and Huang S: Extracellular signal-regulated kinase signaling pathway regulates breast cancer cell migration by maintaining slug expression. Cancer Res 69: 9228-9235, 2009.

17. Hong S, Park KK, Magae J, Ando K, Lee TS, Kwon TK, Kwak JY, Kim CH and Chang YC: Ascochlorin inhibits matrix metalloproteinase- 9 expression by suppressing activator protein1-mediated gene expression through the ERK1/2 signaling pathway: Inhibitory effects of ascochlorin on the invasion of renal carcinoma cells. J Biol Chem 280: 25202-25209, 2005.

18. Lee CS, Cho HJ, Jeong YJ, Shin JM, Park KK, Park YY, Bae YS, Chung IK, Kim M, Kim CH, et al: Isothiocyanates inhibit the invasion and migration of C6 glioma cells by blocking FAK/ JNK-mediated MMP-9 expression. Oncol Rep 34: 2901-2908, 2015.

19. Swiatek-Machado K, Mieczkowski J, Ellert-Miklaszewska A, Swierk P, Fokt I, Szymanski S, Skora S, Szeja W, Grynkiewicz G, Lesyng B, et al: Novel small molecular inhibitors disrupt the JAK/STAT3 and FAK signaling pathways and exhibit a potent antitumor activity in glioma cells. Cancer Biol Ther 13: 657-670, 2012.

20. Shankar A, Kumar S, Iskander AS, Varma NR, Janic B, de Carvalho A, Mikkelsen T, Frank JA, Ali MM, Knight RA, et al: Subcurative radiation significantly increases cell proliferation, invasion, and migration of primary glioblastoma multiforme in vivo. Chin J Cancer 33: 148-158, 2014.

21. Stepanenko AA, Andreieva SV, Korets KV, Mykytenko DO, Baklaushev VP, Huleyuk NL, Kovalova OA, Kotsarenko KV, Chekhonin VP, Vassetzky YS, et al: Temozolomide promotes genomic and phenotypic changes in glioblastoma cells. Cancer Cell Int 16: 36, 2016.

22. Kumar DM,Patil V, Ramachandran B,Nila MV, Dharmalingam $K$ and Somasundaram K: Temozolomide-modulated glioma proteome: Role of interleukin-1 receptor-associated kinase-4 (IRAK4) in chemosensitivity. Proteomics 13: 2113-2124, 2013.

23. Sun S, Wong TS, Zhang XQ, Pu JK, Lee NP, Day PJ, Ng GK, Lui WM and Leung GK: Protein alterations associated with temozolomide resistance in subclones of human glioblastoma cell lines. J Neurooncol 107: 89-100, 2012.
24. Song J, Zhong R, Huang H, Zhang Z, Ding D, Yan H, Sun E and Jia X: Combined treatment with Epimedium koreanum Nakai extract and gefitinib overcomes drug resistance caused by T790M mutation in non-small cell lung cancer cells. Nutr Cancer 66: 682-689, 2014

25. Geng YD, Yang L, Zhang C and Kong LY: Blockade of epidermal growth factor receptor/mammalian target of rapamycin pathway by Icariside II results in reduced cell proliferation of osteosarcoma cells. Food Chem Toxicol 73: 7-16, 2014.

26. Jiang Y, Han Y, Sun C, Han C, Han N, Zhi W and Qiao Q: Rab23 is overexpressed in human bladder cancer and promotes cancer cell proliferation and invasion. Tumour Biol 37: 8131-8138, 2016.

27. Xu B, Jiang C, Han H, Liu H, Tang M, Liu L, Ji W, Lu X, Yang X, Zhang Y, et al: Icaritin inhibits the invasion and epithelial-tomesenchymal transition of glioblastoma cells by targeting EMMPRIN via PTEN/AKt/HIF-1 $\alpha$ signalling. Clin Exp Pharmacol Physiol 42: 1296-1307, 2015.

28. Kiseleva LN, Kartashev AV, Vartanyan NL, Pinevich AA and Samoilovich MP: A172 and T98G cell lines characteristics. Cell Tissue Biol 58: 349-355, 2016.

29. Zhao Y, Xiao A, diPierro CG, Carpenter JE, Abdel-Fattah R, Redpath GT, Lopes MB and Hussaini IM: An extensive invasive intracranial human glioblastoma xenograft model: Role of high level matrix metalloproteinase 9. Am J Pathol 176: 3032-3049, 2010.

30. Shi C, Zhang N, Feng Y, Cao J, Chen X and Liu B: Aspirin inhibits IKK- $\beta$-mediated prostate cancer cell invasion by targeting matrix metalloproteinase-9 and urokinase-type plasminogen activator. Cell Physiol Biochem 41: 1313-1324, 2017.

31. Choe G, Park JK, Jouben-Steele L, Kremen TJ, Liau LM, Vinters HV, Cloughesy TF and Mischel PS: Active matrix metalloproteinase 9 expression is associated with primary glioblastoma subtype. Clin Cancer Res 8: 2894-2901, 2002.

32. Liu MF, Hu YY, Jin T, Xu K, Wang SH, Du GZ, Wu BL, Li LY, $\mathrm{Xu}$ LY, Li EM, et al: Matrix metalloproteinase-9/neutrophil Gelatinase-Associated lipocalin complex activity in human glioma samples predicts tumor presence and clinical prognosis. Dis Markers 2015: 138974, 2015.

33. Veeravalli KK and Rao JS: MMP-9 and uPAR regulated glioma cell migration. Cell Adhes Migr 6: 509-512, 2012.

34. Gondi CS, Lakka SS, Dinh DH, Olivero WC, Gujrati M and Rao JS: Downregulation of UPA, uPAR and MMP-9 using small, interfering, hairpin RNA (siRNA) inhibits glioma cell invasion, angiogenesis and tumor growth. Neuron Glia Biol 1: 165-176, 2004.

35. Pan HC, Jiang Q, Yu Y, Mei JP, Cui YK and Zhao WJ: Quercetin promotes cell apoptosis and inhibits the expression of MMP-9 and fibronectin via the AKT and ERK signalling pathways in human glioma cells. Neurochem Int 80: 60-71, 2015.

36. Shoji T, Kobori M, Shinmoto $H$, Tanabe $M$ and Tsushida $T$ : Progressive effects of phloridzin on melanogenesis in B16 mouse melanoma cells. Biosci Biotechnol Biochem 61: 1963-1967, 1997.

37. Chen CM, Hsieh YH, Hwang JM, Jan HJ, Hsieh SC, Lin SH and Lai CY: Fisetin suppresses ADAM9 expression and inhibits invasion of glioma cancer cells through increased phosphorylation of ERK1/2. Tumour Biol 36: 3407-3415, 2015.

38. Zhang W, Murao K, Zhang X, Matsumoto K, Diah S, Okada M, Miyake K, Kawai N, Fei Z and Tamiya T: Resveratrol represses YKL-40 expression in human glioma U87 cells. BMC Cancer 10: 593,2010

39. Zhang XJ, Wang YH, Gao S, Guo LY, Li HH and Song MY: Relationship between gestational glucose, lipid metabolism parameters and fetal distress. Zhonghua Liu Xing Bing Xue Za Zhi 37: 876-879, 2016 (In Chinese).

40. Zhou X, Hua L, Zhang W, Zhu M, Shi Q, Li F, Zhang L, Song C and Yu R: FRK controls migration and invasion of human glioma cells by regulating JNK/c-Jun signaling. J Neurooncol 110: 9-19, 2012.

41. Hao XN, Wang WJ, Chen J, Zhou Q, Qu YX, Liu XY and Xu W: Effects of resveratrol on ARPE-19 cell proliferation and migration via regulating the expression of proliferating cell nuclear antigen, P21, P27 and p38MAPK/MMP-9. Int J Ophthalmol 9: 1725-1731, 2016.

42. Lin CC, Chen JT, Yang JS, Lu HF, Hsu SC, Tan TW, Lin YT, Ma YS, Ip SW, Wu JJ, et al: Danthron inhibits the migration and invasion of human brain glioblastoma multiforme cells through the inhibition of mRNA expression of focal adhesion kinase, Rho kinases-1 and metalloproteinase-9. Oncol Rep 22: 1033-1037, 2009. 